\title{
NAQOYQATSI, ou o movimento como (des)controle ${ }^{1}$
}

\begin{abstract}
André Bonotto ${ }^{2}$
Resumo: Este artigo apresenta uma análise do filme Naqoyqatsi (2002), parte da trilogia Qatsi, dirigida por Godfrey Reggio. Centramos nossa análise no regime imagético-narrativo complexo que se constrói através do uso de imagens eletrônicas e imagens de arquivos as mais diversas. Apoiaremos-nos em características fundamentais da natureza das imagens que compõem a narrativa: virtualidade; resíduo de operação pelo uso de imagens de arquivo; fluxo vertiginoso pelas imagens aceleradas; análise de desempenho pelas imagens desaceleradas. Estas características reverberam nos dois movimentos que se chocam, suscitados pelas imagens: aceleração/caos; e desaceleração/controle.
\end{abstract}

Palavras-chave: Naqoyqatsi. Trilogia Qatsi. Imagens eletrônicas. Imagens de arquivo. Imagens aceleradas/desaceleradas.

\begin{abstract}
This article presents an analysis of the film Naqoyqatsi (2002) that is a part of the Qatsi trilogy, directed by Godfrey Reggio. The analysis centers on the complex imagetic-narrative regime, constituted through large use of electronic images and diverse archive footage. Some fundamental characteristics of the images' nature that compose the narrative are observed: virtuality; operational residue from the use of archive footage; vertiginous flux from the use of accelerated images; performance analysis from the use of slowed images. These characteristics reverberate toward both movements that collide, raised by the images: acceleration/chaos; and slowdown/control.
\end{abstract}

Key-words: Naqoyqatsi. Qatsi trilogy. Eletronic images. Archive footage. Accelerated/slowed images.

Naqoyqatsi (2002) é o filme que encerra a trilogia Qatsi, realizada pelo diretor americano Godfrey Reggio, iniciada com Koyaanisqatsi (1983) e continuada com Powaqqatsi (1988). Os filmes da trilogia mantêm entre si uma continuidade estética, articulando grandes blocos seqüenciais de imagens heterogêneas com trilhas musicais instrumentais constantes, constituindo assim uma estilística fílmica chamada de "não-verbal", posto que as narrativas destes filmes não se utilizam da palavra ou da fala para se articularem.

\footnotetext{
${ }^{1}$ Este trabalho consiste de versão revisada do quarto capítulo da dissertação de mestrado Trilogia Qatsi: visões e movimentos de mundo (BONOTTO, 2009). Agradecemos à Fapesp pelo suporte à realização da dissertação.

${ }^{2}$ Mestre e doutorando em Multimeios Unicamp. Email: andrebonotto@ yahoo.com.br.
} 
Naqoyqatsi compõe um estado de coisas dos modos de vida globalizados, pósmodernos e pós-industriais ${ }^{3}$, modos de vida totalmente integrados com um ambiente digital, virtual. Trata-se de um universo de códigos e fórmulas, mediações e simulações, onde tudo isso está posto a serviço de um impulso controlador e ao mesmo tempo desestabilizador; um impulso bélico (Naqoyqatsi $=$ vida como guerra).

Enquanto que para a realização dos dois primeiros filmes da trilogia Qatsi o diretor efetuou a operação de sair ao mundo histórico e tomar imagens que seriam recombinadas numa composição visual criativa (simultânea a uma composição musical de semelhante interesse), Naqoyqatsi envereda por um processo de realização diferente. Em Naqoyqatsi, a própria concepção de tomada, da relação de uma imagem com o mundo, será colocada em questão. $\mathrm{O}$ filme re-trabalha uma grande quantidade de imagens de arquivo, transformando as mais diversas características das imagens originais, o que, misturado à infindável quantidade de imagens geradas por computador e por instrumentos técnico-científicos, nos impede de perceber, em certas passagens, se estamos a ver um tomada manipulada em pós-produção, ou uma imagem inteiramente gerada por computador.

Para que possamos então desenvolver nossa análise desta narrativa fílmica, necessitamos antes observar e tentar organizar esse complexo visual.

\section{Arqueologia visual-dissolutiva}

Como dissemos, a narrativa de Naqoyqatsi se compõe utilizando imagens dos tipos mais diversos, como se estivéssemos a atravessar (ou fôssemos atravessados por) um imenso "banco de imagens".

Em meio a todo esse acervo, podemos agrupar certos tipos de imagem, presentes mais maciçamente:

a) tomadas realizadas em primeira mão, nas quais reconhecemos que a câmera se encontra num espaço físico específico, a registrar uma situação;

\footnotetext{
${ }^{3}$ Quase três décadas separam a realização deste terceiro filme da realização do primeiro filme, Koyaanisqatsi, iniciado em 1975 mas lançado apenas em 1983, de modo que o primeiro filme apresenta processos de industrialização que consideraríamos hoje já bem superados, daí utilizarmos o termo "pós-industriais" para distinguir o estado de coisas apresentado por este terceiro filme. Para maiores informações quanto a trajetória de Godfrey Reggio e sua filmografia, sugerimos a leitura do texto Biofilmografia de Godfrey Reggio (BONOTTO; TEIXEIRA, 2009).
} 

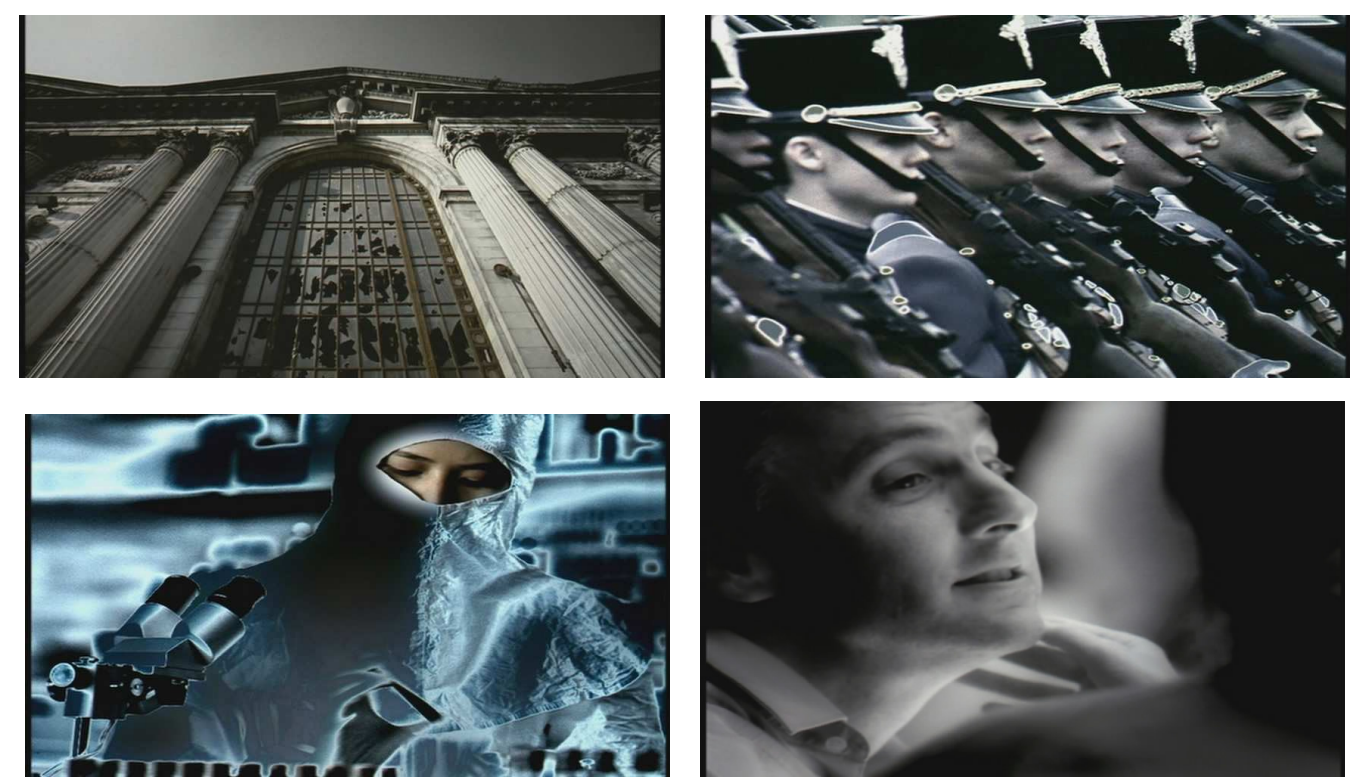

Figura 1: Tomadas

b) pinturas, reconhecíveis imediatamente como tais ou manipuladas digitalmente, tornando complexo seu deciframento;
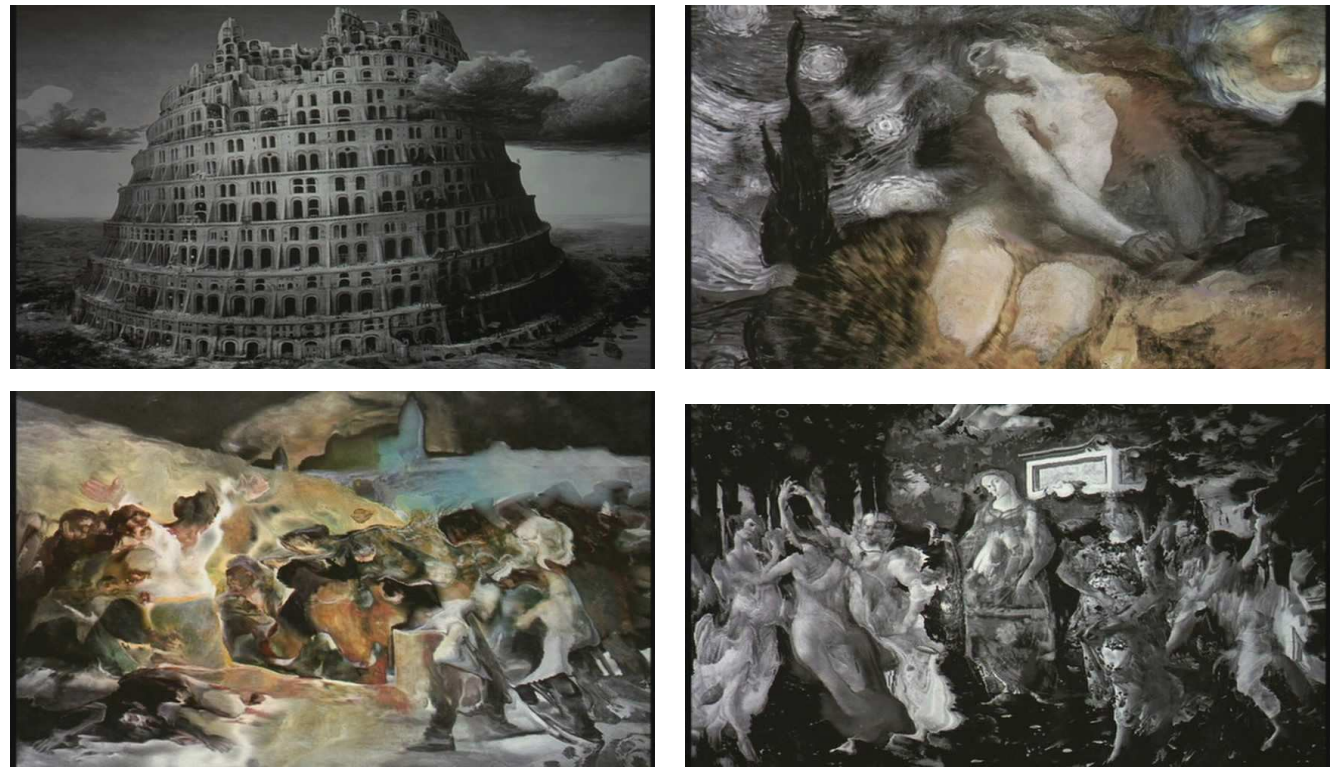

Figura 2: Pinturas

c) imagens de arquivo, que aparecem contendo certo "resíduo de operação" que indica seu pertencimento a contextos outros ${ }^{4}$;

\footnotetext{
${ }^{4}$ Jean-Claude Bernardet (2004) pensa essa situação de "transposição de uma imagem de um contexto fílmico para outro", tomando por base os filmes que realizou baseados na montagem de imagens de arquivo (imagens de outros filmes). A imagem não apenas migra de um contexto a outro, mas ocorre também uma transposição de um "resíduo de operação" entre eles, no qual aspectos da imagem/ contexto originais saltam-nos aos olhos nesse novo locus, chamando atenção para especificidades históricas ou semióticas, especificidades que ganham maior relevo quanto maior a distância de tempos e contextos.
} 

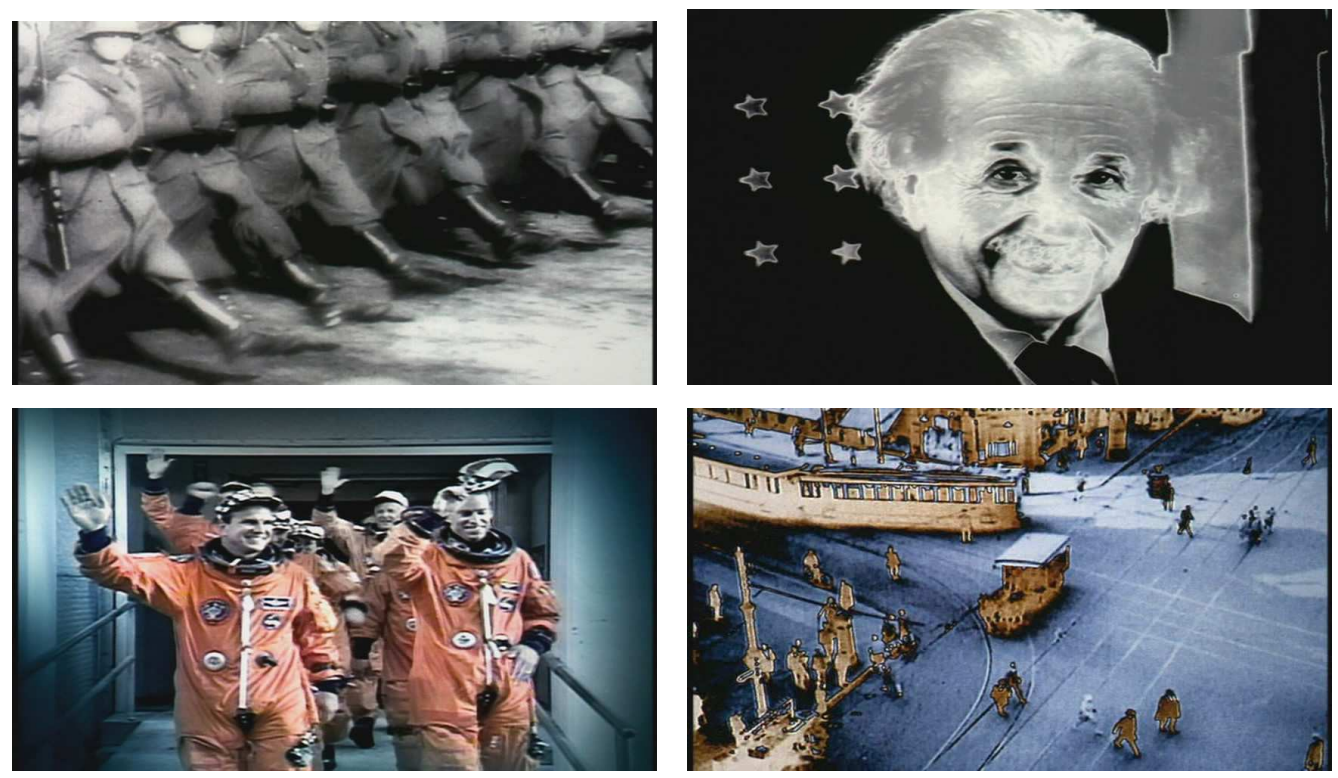

Figura 3: Imagens de arquivo

d) imagens midiáticas, que indicam sua existência ter se dado através da circulação pela mídia de massa (muitas vezes apresentando uma textura própria a essa circulação - um tipo de resíduo de operação -, como por exemplo, a pixelização oriunda do monitor televisivo, ou o aspecto clean da publicidade mais naturalista), podendo advir de telejornais ou noticiários, jogos esportivos, filmes ficcionais, filmes de animação, filmes publicitários, videogames etc.;
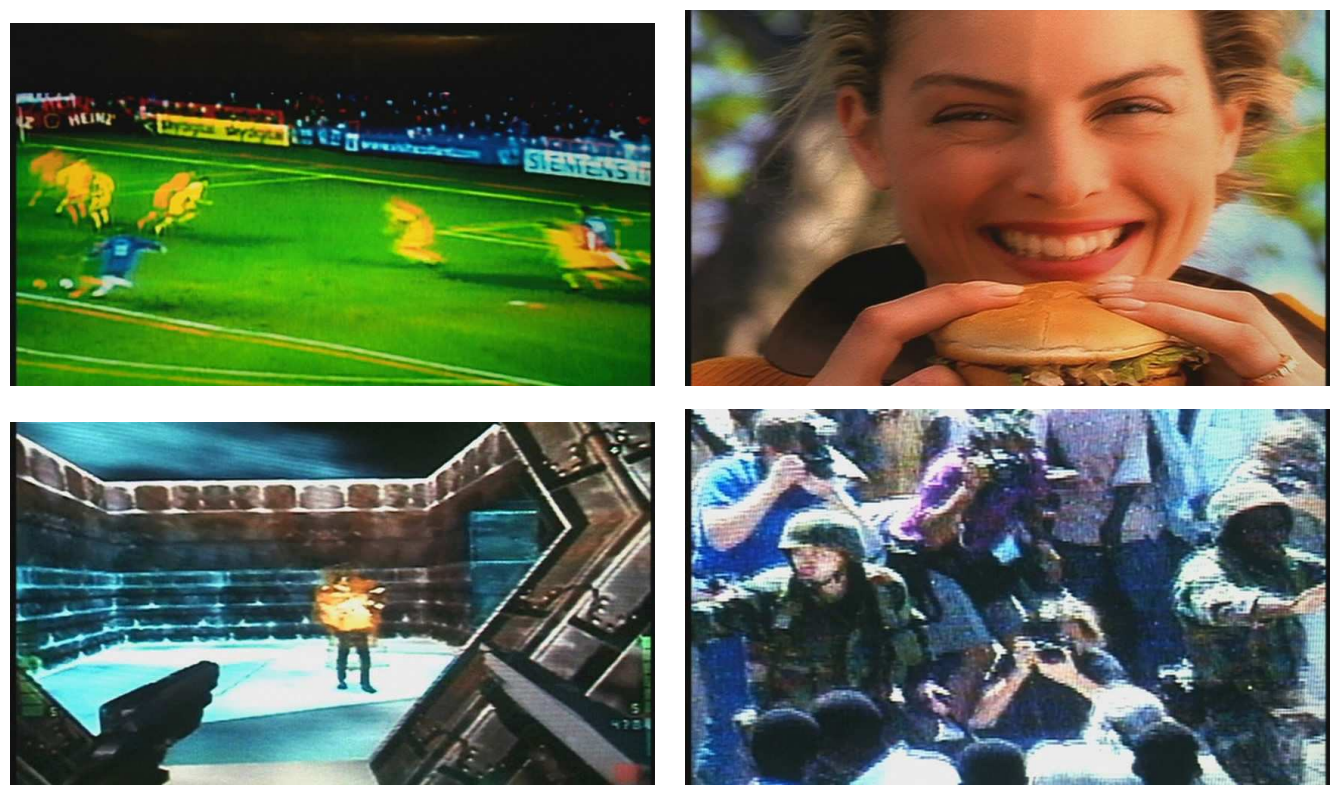

Figura 4: Imagens midiáticas

e) imagens científicas, podendo ser de mostradores ou displayers de equipamentos, obtidas no sinal de saída de visualização de aparelhos eletrônicos como radiografias e ressonâncias, ou podem ainda ser imagens instrumentais como esquemas e fórmulas matemáticos, ligações químicas, mapas do sistema solar, plantas matemático-arquitetônicas, 
modelagem tridimensional de sólidos geométricos, do corpo humano, ou de outras estruturas, ou também imagens microscópicas, fractais, lembrando ainda das imagens fotografadas pelos estudos de movimento de Muybridge;
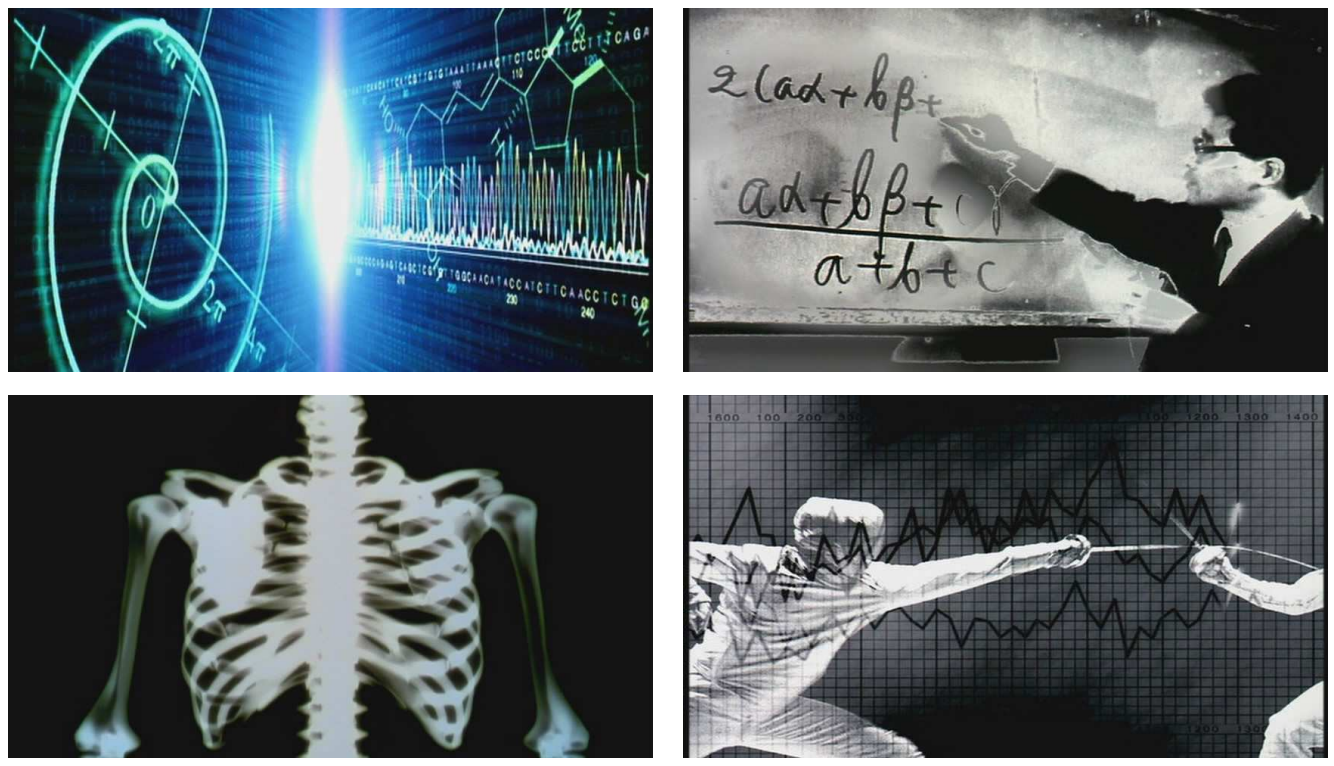

Figura 5: Imagens científicas

f) imagens de sintese numérica, aquelas criadas ou modeladas por computação gráfica, como a criação de espaços geográfico-geológicos, modelagem de globos em versões diversas, ambientes eletrônicos de interiores de aparelhos, interiores de túneis, base de plantas arquitetônicas urbanas, partes ou totalidades de personagens sobrepostos aos reais, imagens espaciais, símbolos financeiros, culturais ou logomarcas realizados como "objetos" tridimensionais etc.; isso tudo ainda somado às multiplicações do código binário (0's e 1's) e outros caracteres, e às manipulações digitais diversas pelo que passam todas essas imagens listadas (como a alternação, inversão, saturação, de-saturação ou aberração cromática, composição de planos e elementos visuais diversos por recortes, sobreposições e transparências múltiplos, ou ainda a aceleração, desaceleração, retrocesso, repetição, ou mudança de direção do movimento).
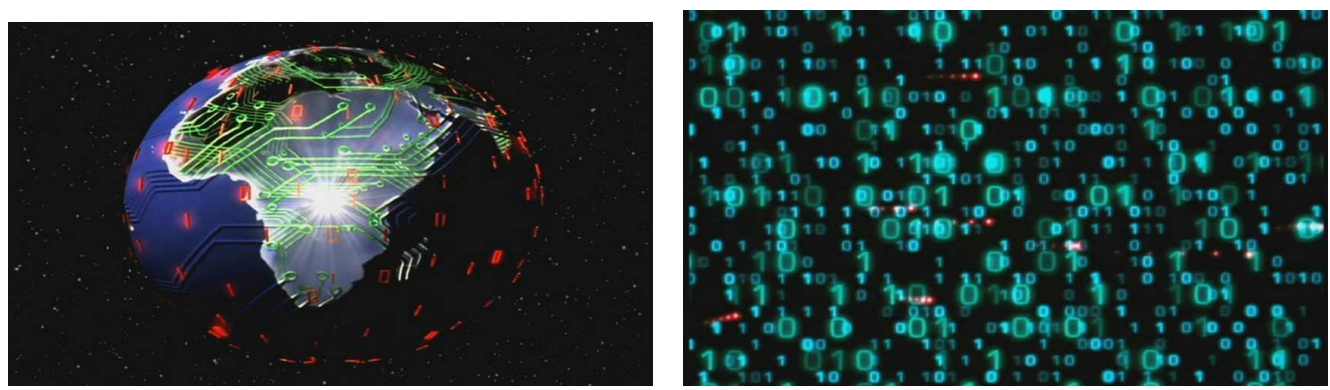

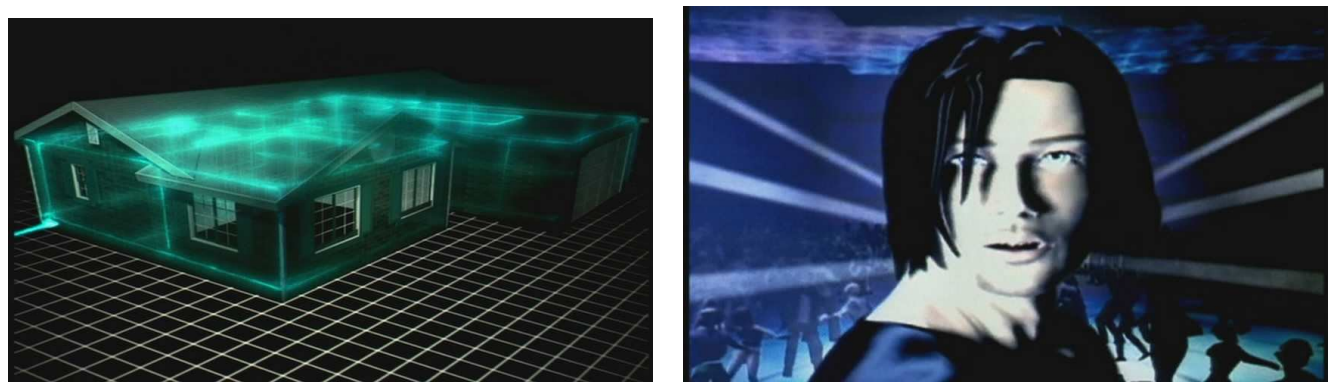

Figura 6: Imagens de síntese numérica

A lista, que já pode ser o início de uma arqueologia visual do filme, é longa e dificilmente extensiva a toda a nuance da variedade imagética de que dispõe a narrativa fílmica, mesmo porque várias destas "categorias" surgem combinadas.

Pois bem, dentre essa grande diversidade de material visual, detectamos a princípio a proeminência das imagens técnicas.

A imagem técnica em sua acepção mais comum seria "toda representação plástica enunciada por ou através de algum dispositivo técnico" (MACHADO, 2007: p. 222). Ou, já que esse tipo de designação levanta problemas quanto à profundidade e extensão do entendimento do adjetivo "técnica", poderíamos colocar esse mesmo dado no foco do problema, e entender o termo "imagem técnica" como uma designação geral de "uma classe de fenômenos audiovisuais em que o adjetivo ('técnica') de alguma forma ofusca o substantivo ('imagem')" (p. 224), o que nos remete rapidamente às imagens que trabalham com processos eletro-químicos: fotografia e vídeo analógicos ou digitais, cinematografia, imagens trabalhadas por computação gráfica, etc.

Em Naqoyqatsi, as imagens técnicas aparecem sobretudo na forma de imagens de arquivo, imagens midiáticas, imagens científicas ou imagens digitais de síntese numérica ${ }^{5}$, sendo estas últimas aquelas imagens geradas ou processadas por computador (Cf. MACHADO, 2007: p. 231) e que, portanto, operam em sua criação ou transmissão através do código binário.

No transcorrer do filme, vemos as imagens de síntese ganharem cada vez maior relevo, através da criação de ambientes e personagens tridimensionais que se mesclam a (ou substituem) os reais; através da modelagem dos corpos, objetos e estruturas; ou na composição mesma desse "ambiente virtual" que parece ir se formando à medida que a narrativa transcorre, ambiente no qual todas as outras imagens parecem vir a se inserir.

\footnotetext{
${ }^{5}$ Utilizaremos esses termos indiferenciadamente ao longo do trabalho: imagem digital, imagem numérica, ou imagem de síntese; para se referir ao mesmo tipo de fenômeno imagético.
} 
Desta forma, colocando como central a presença das imagens de síntese, devemos explorar uma de suas características que se mostrará de grande importância. Notemos que para a imagem computadorizada, “(...) na realidade, imagem alguma é armazenada num arquivo de computação gráfica, mas apenas funções matemáticas organizadas num programa" (MACHADO, 1988: pp. 139-140). Deve-se ficar claro que “(...) a atualização de uma imagem não esgota as possibilidades de visualizá-la, pois o programa, na maioria das vezes, tem sempre infinitas maneiras de exibir um único objeto" (p. 145).

Há aqui uma qualidade fundamental da imagem de síntese que estamos tentando demarcar, que é seu estado de virtualidade: o reconhecimento deste tipo de imagem como “(...) atualização provisória de um campo de possibilidades” (p. 145). Com isso, esses dados latentes na memória computacional - o "campo de possibilidades" - funcionam como “objetos” que podem vir a “(...) sofrer qualquer sorte de manipulações, através da pura e simples alteração de seus valores numéricos" (MACHADO, 1996: p. 60) - sua atualização.

E dentre todas as manipulações possíveis, exploradas diversificadamente em Naqoyqatsi, temos uma que se destaca: a multiplicação de elementos visuais. Um impulso presente no filme é o de multiplicação dos vários “objetos” presentes numa memória virtual, criando várias "versões" de um mesmo objeto, podendo haver ainda uma variação em alguma das propriedades de cada versão. Tal operação entra ainda num jogo com as tomadas nas quais há padrões visuais recorrentes.
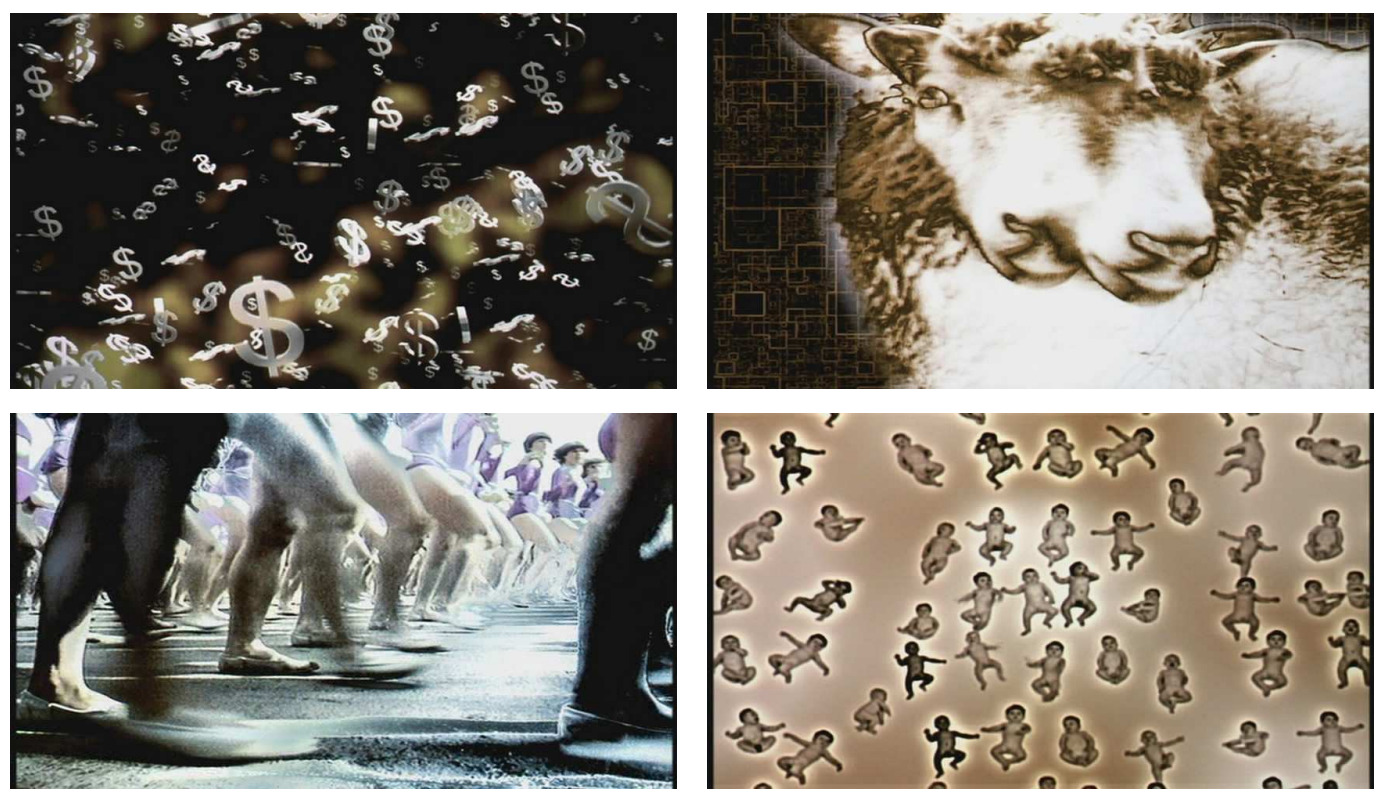

Figura 7: Multiplicação de elementos visuais e padrões visuais recorrentes

É isso o que ocorre com os planos duplicados sobrepostos (como o da ovelha); é o que também ocorre com os símbolos ou caracteres binários que aparecem como "objetos tridimensionais"; e é o que ocorre ainda com elementos visuais discretos "multiplicados" 
(como nas imagens de incontáveis corpos microscópicos em laboratório ou os inúmeros bebês deitados - sendo ambos exemplos que remetem à clonagem). Daremos ainda à multiplicação uma outra dimensão, como se verá mais adiante (na quarta seção deste texto). Por ora, entendida a qualidade virtual das imagens numéricas, passemos a explorar sua aparição e funcionamento na narrativa de Naqoyqatsi.

Além dos casos mais explícitos de aparição das imagens sintéticas como objetos imediatamente identificáveis como tal (modelagem de sólidos geométricos e outros construtos), pensamos haver um impulso diluído por todo o filme no sentido de imbricar essas imagens tão a fundo em meio a outras, de modo que não mais consigamos discerni-las em definitivo. Podemos ver esse impulso manifesto de forma mais consistente em certas passagens fílmicas, dentre as quais destacamos quatro delas:

1) Na seqüência de abertura $^{6}$, onde, após a fusão de plano das águas marítimas agitadas com planos panorâmicos de montanhas sob céu com "chuva de estrelas" 7 , há uma tomada acelerada com câmera em movimento, rente à água, rodeada por rochas e montanhas, e as nuvens passam rapidamente. Passa-se então a um plano onde uma câmera aérea em movimento rasante sobre o solo percorre uma estranha paisagem rochosa, de onde um pico montanhoso irrompe em ascensão, até atingir as nuvens.
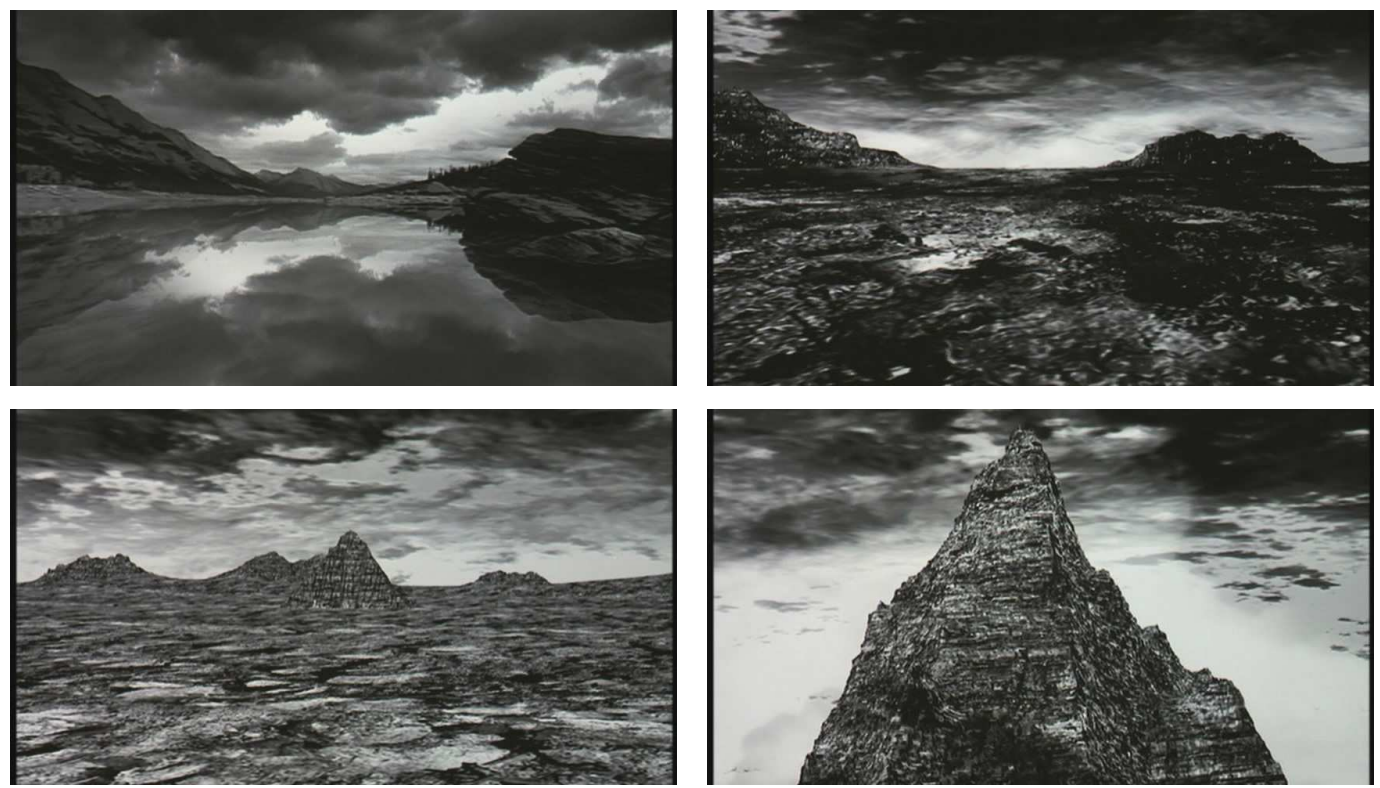

Figura 8: Sequiência de abertura: paisagem natural é substituída por paisagem virtual

\footnotetext{
6 Para informações mais detalhadas a respeito da divisão das sequiências nos filmes da trilogia Qatsi, recomendamos consulta à Introdução e ao Apêndice I de Trilogia Qatsi: visões e movimento de mundo (BONOTTO, 2009). De maneira geral, pode-se acompanhar as mudanças das sequiências fílmicas através da observação das mudanças das longas faixas musicais. Além da apresentação de algumas imagens a que nossa análise se refere, procuramos situar as nossas remissões a passagens fílmicas através de nota de rodapé informando o tempo de projeção do filme (contado a partir da aparição da logomarca animada da Miramax) em que se encontra a passagem ou elemento citado.

${ }^{7}$ Aproximadamente aos 5'30', de filme.
} 
2) Na terceira seqüência, onde há um movimento de travelling dos pés à cabeça de um esqueleto humano ${ }^{8}$, sucedido por uma imagem translúcida de uma cabeça humana. Um pouco mais à frente, há uma tomada de homem deitado em máquina de ressonância, seguida por um modelo tridimensional de uma cabeça humana girando, sucedida por modelos da coluna vertebral e do cérebro, e ainda três modelos de corpos humanos (como radiografias tridimensionais girando), onde se vêm as estruturas ósseas e os órgãos internos. Essa série finaliza com um detalhe aproximado de pedaço da coluna vertebral e de secção da cabeça.
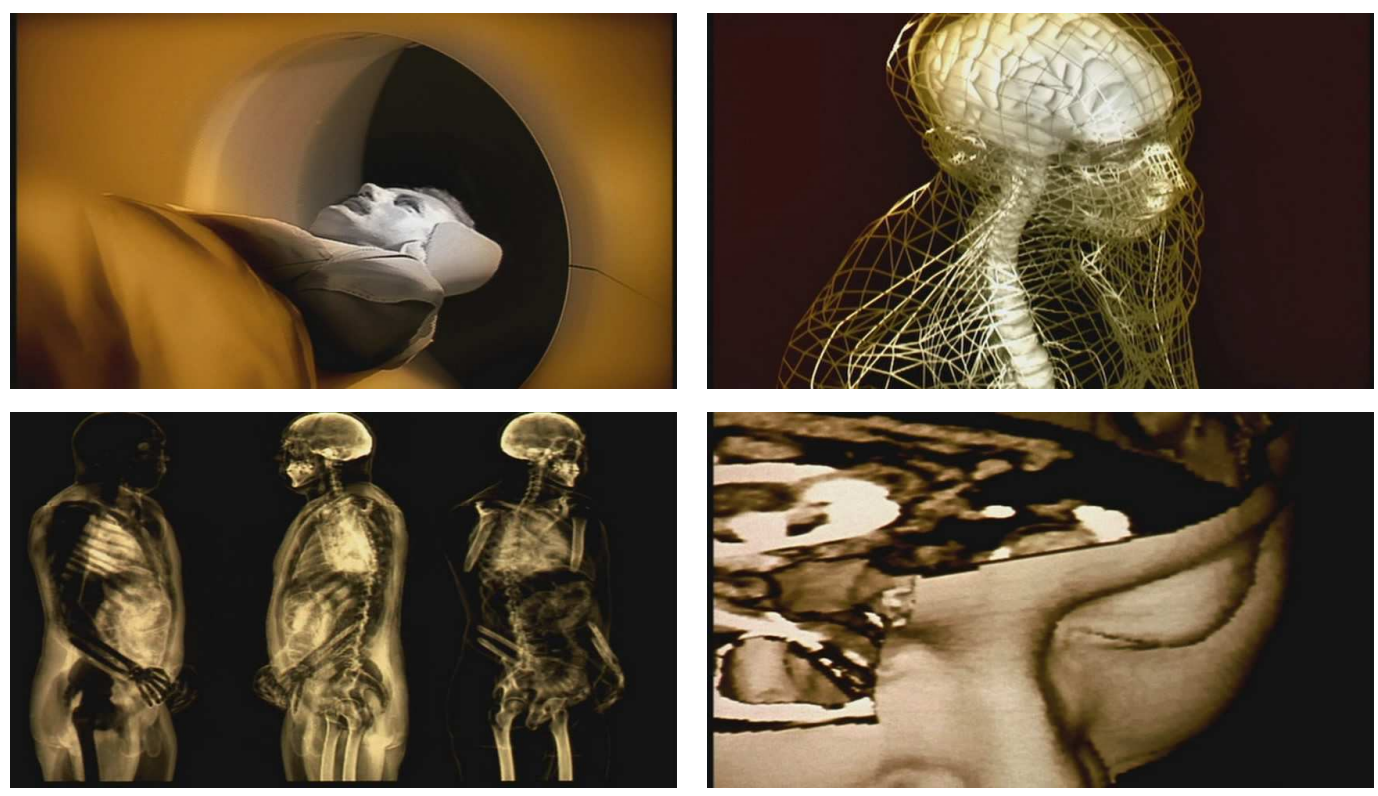

Figura 9: Terceira sequiência: modelagem virtual do interior do corpo humano

3) Na quinta seqüência, dentre tomadas agitadas de repórteres em cobertura midiática de celebridades, políticos e outras "celebridades", há um plano onde uma personagem modelada em computação gráfica desce de uma limusine, cumprimenta os repórteres e percorre o tapete vermelho. Fora essa personagem, todo o resto da imagem provém da tomada captada nessa situação descrita. Mais à frente, dentre flashes de câmera diversos e personagens modelados por computação gráfica, temos duas repetições de uma mesma tomada mostrando uma celebridade entrar em palco de um programa televisivo, acenar ao público e cumprimentar o apresentador. A cada repetição, há sobre a imagem do corpo da celebridade uma imagem de um corpo e vestes diferentes, modelados digitalmente, se sobrepondo totalmente ao corpo original, inclusive quanto à flexibilidade do movimento realizado. Após isso, seguem-se tomadas de outras celebridades diversas (Marilyn Monroe, Marlon Brando, Elton John etc.).

\footnotetext{
${ }^{8}$ Aproximadamente aos 18'12', de filme.

9 Aproximadamente a partir dos 38'16', de filme.
} 

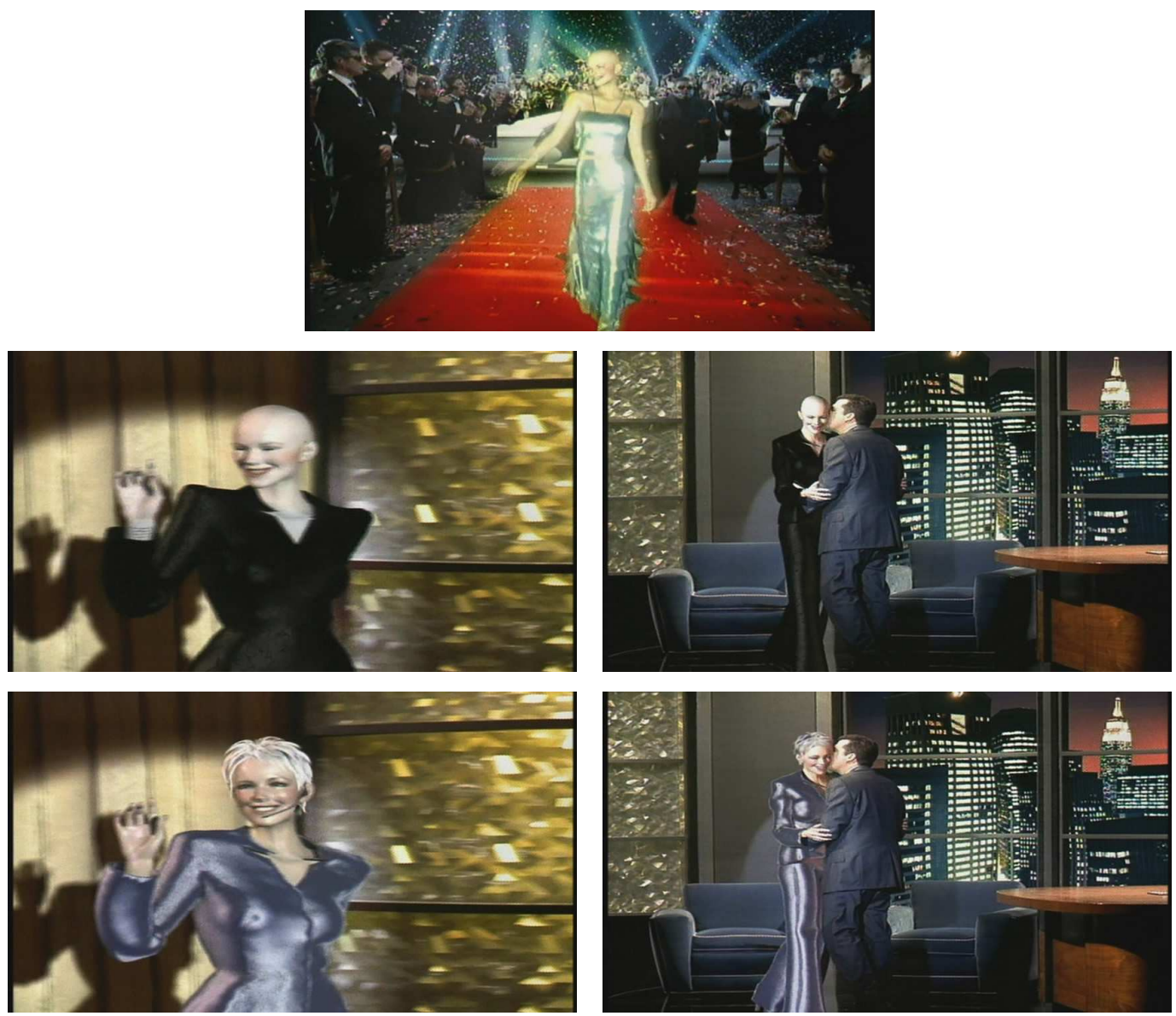

Figura 10: Quarta seqüência: modelagem virtual do exterior do corpo humano

4) $\mathrm{Na}$ décima seqüência (última seqüência anterior aos créditos) em meio a imagens desfocadas e fusões diversas de luzes e silhuetas vagas, onde surgem as figuras dos páraquedistas e astronautas ${ }^{10}$, compõe-se um ambiente espacial-sideral difuso com os seguintes planos: plano no qual a câmera atravessa uma chuva de meteoros; plano do lançamento de um foguete (objeto modelado digitalmente) para fora da Terra, com esta vista ao fundo; plano de céu totalmente negro com a "chuva" de traços estelares; plano do lançamento de um ônibus espacial, novamente com a Terra ao fundo; planos de fundo espacial sobrepostos por outras imagens; planos dos astronautas à deriva no espaço; plano final do espaço, como se estivesse em movimento, "tragando" o pára-quedista.
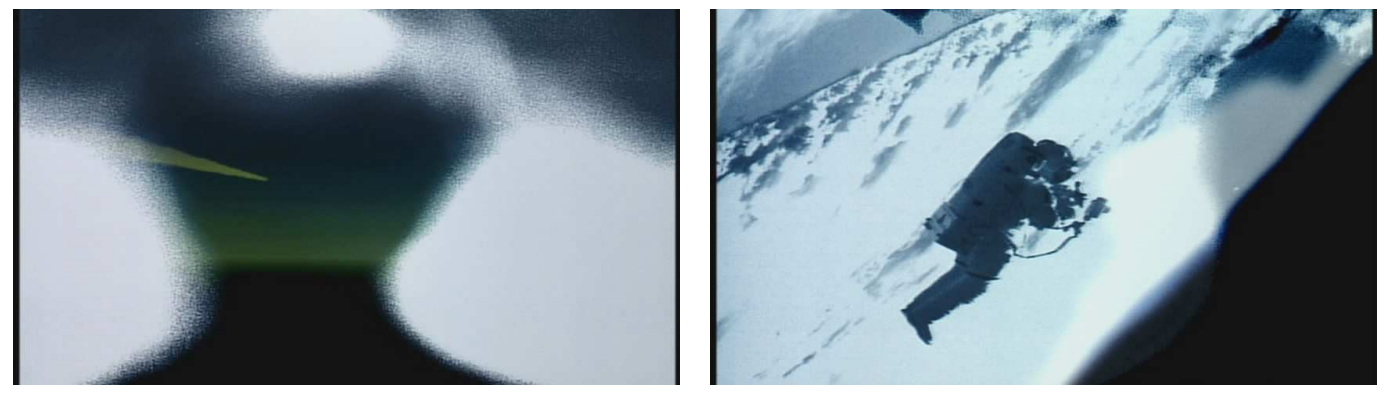

\footnotetext{
${ }^{10}$ Aproximadamente aos 79'50', de filme.
} 

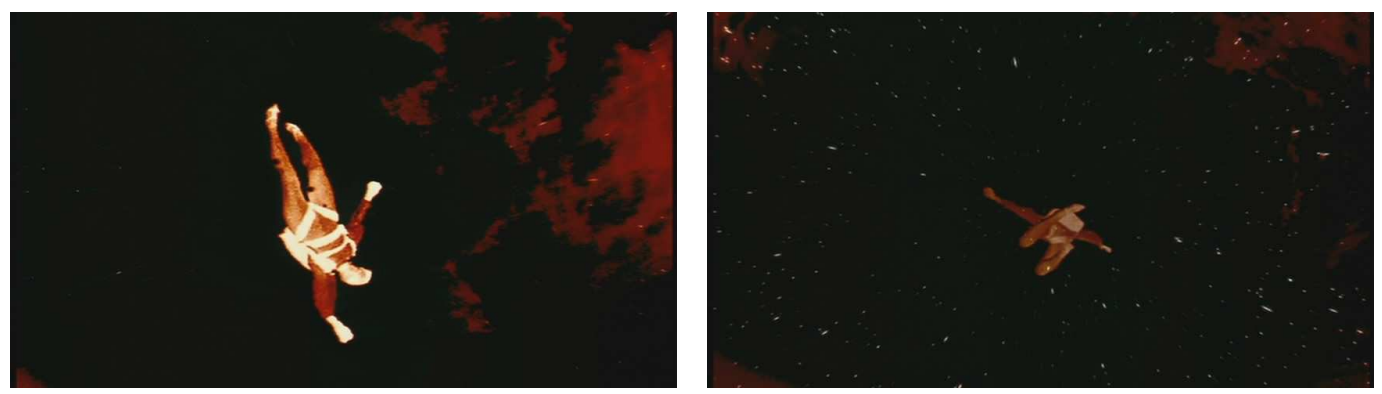

Figura 11: Décima seqüência: ambiente espacial e astronauta/pára-quedista

As ligações entre as combinações de imagens das passagens examinadas aqui sugerem, no primeiro caso, uma indiscernibilidade entre ambiente real e simulado, ao passarmos de tomadas de locações montanhosas para um plano onde uma montanha modelada digitalmente irrompe em um solo que não sabemos mais se tem alguma parte de referente real em sua construção na imagem.

No segundo momento, essa indiscernibilidade entre objeto real e simulado passa à própria estrutura interna dos corpos humanos (dentre outras estruturas espalhadas pelo filme), ao passarmos por imagens as quais não conseguimos mais distinguir se foram obtidas pelos aparelhos de radiografia/ ressonância, caso em que seriam, portanto, espécies de "tomadas" realizadas diante dos próprios corpos (que funcionariam como referentes específicos), ou se são, ao invés disso, imagens de síntese baseadas em modelos conceituais das estruturas internas humanas em geral, ou seja, "atualização dos dados" de uma "memória virtual".

No terceiro exemplo, a indiscernibilidade se generaliza aos exteriores dos corpos, entre sua aparência real ou imagem simulada. As partes de corpos ou corpos completos de personagens modelados digitalmente se sobrepõem, se colam, sobre os espaços preenchidos originalmente por algum corpo real, e absorvem de tal forma o movimento destes (já que não vemos os originais "vazarem" por baixo durante o movimento) que as simulações parecem interagir realmente com os outros elementos da tomada - estes outros, registrados in loco.

E por último, no quarto exemplo, imiscuem-se imagens diversas do espaço, essa região não muito acessível aos nossos meios técnicos mais ordinários, o que nos impede de reconhecer mais prontamente uma "tomada real" de tal região, de um plano simulado. Já não bastasse essa dificuldade de reconhecimento inicial, esses planos do espaço ainda recebem muitas imagens sobrepostas simultaneamente, compondo uma complexa combinatória de elementos visuais difusos sobre esse espaço dado como "plano de fundo". Esse espaço como plano de fundo, o qual a princípio se indiscerne entre tomada real ou simulada, esse ambiente espacial como espécie de "tela", vinha estando presente de forma diluída, em verdade, durante 
grande parte do filme, como nos casos de esvaziamento total do quadro pelas telas brancas ou negras - o que funciona como transição entre várias seqüências fílmicas.

Se havíamos considerado anteriormente a imagem digital como essencialmente uma imagem virtual a ser atualizada, podemos agora ver mais claramente os vetores de indiscernibilidade entre o real e o virtual que a narrativa compõe, ainda que ela o faça de maneira fragmentada e esparsa durante seu transcorrer: indiscernibilidade entre espaço real e virtual; indiscernibilidade entre interiores/estruturas de corpos reais ou virtuais; indiscernibilidade entre exteriores/aparências de corpos reais ou virtuais; e por fim, uma potência de indiscernibilidade que engloba a todas as outras imagens, entre realidade ou virtualidade de um espaço como suporte (ou ambiente), sobre o qual gravitam todos os outros corpos, todas as outras imagens do filme.

Este espaço como suporte, espaço real ou virtual que traga o pára-quedista ao final da narrativa, nos mantém sob constante dúvida, indecidibilidade, de que se ao menos alguma dessas imagens, desses corpos pelos quais passamos durante toda a narrativa, se ao menos algum deles teria sido "real", teria "vindo realmente do mundo" (ou de suas proximidades), e não sido uma imagem completamente criada, produzida.

Dentre essas indiscernibilidades todas, o que vemos ocorrer é uma dissolução da noção mesma de tomada e de plano, noções que supõem que uma configuração imagética dada em determinado momento pela narrativa é derivada de parâmetros visuais tais como: dimensão do campo visível, tamanho do espaço delimitado em relação ao motivo visual, ângulo ou ponto de vista em relação a este motivo, ritmo e trajetória de movimento deste motivo num espaço físico registrado, duração do registro etc. (Cf. AUMONT et al., 2007: pp. 38-44). Estes parâmetros atribuídos à tomada/plano assimilam a imagem visível num dado momento da narrativa à presença física de uma câmera num espaço real num tempo passado, no qual a câmera teria se comportado segundo a codificada pirâmide visual obtida por um suposto corpo humano presente neste mesmo espaço, em sua postura vertical ereta.

Por outro lado, havendo imagens modeladas ou simuladas independentemente de um referencial a se colocar de frente a uma câmera, deixa-se de haver necessariamente uma tomada. E havendo ainda transformações múltiplas de objetos modelados, e fluxos visuais simultâneos, ambos persistindo sua presença entre-imagens, deixa-se de haver necessariamente um plano, já que não estamos mais aptos a distinguir suas delimitações.

As imagens vistas em Naqoyqatsi têm a potência de se desprenderem de sua suposta geração por uma câmera. O que esse complexo de indiscernibilidades e dissoluções faz, na narrativa, é tornar indecidível a origem, referencialidade e outras qualidades de cada objeto 
dessa arqueologia visual, em relação a seu "pertencimento ao mundo". Nessas condições, a tela não pode mais funcionar como espécie de "janela aberta para o mundo". A

própria tela, mesmo se ainda conserva a posição vertical por convenção, não parece mais remeter à postura humana, como uma janela ou ainda um quadro, mas constitui antes uma mesa de informação, superfície opaca sobre a qual se inscrevem "dados", com a informação substituindo a Natureza (...) (DELEUZE, 1990: p. 315).

Temos uma tela-ambiente virtual (em oposição agora, a um ambiente "natural") que funciona como mesa de informações, na qual se inscrevem combinações de dados-imagens que se esboçam, e tão logo se traçam, já se dissolvem vertiginosamente. Há choques e deslizamentos de imagens-dados, umas sobre as outras, com suas revoluções e dissoluções nessa tela-mesa de informações virtual.

Tal é a situação do regime visual deste filme, ao qual poderíamos nos referir como compondo uma arqueologia visual-dissolutiva, com seus diversos estratos mais ou menos fluidos, instáveis, sempre se escoando. Daremos continuidade a exploração desse regime visual, a seguir, com seus movimentos conseqüentes.

\section{Aceleração/caos}

Ao tomarmos este "ambiente de imagens" que é a tela, não mais como uma "janela" ou "quadro", ao observarmos que as próprias noções de "tomada" ou "plano" acabam por esvaziar-se, constatamos que necessitamos abordar diferentemente as imagens agenciadas por esta narrativa fílmica.

Seria o caso de se pensar essas passagens de imagens ${ }^{11}$ as quais temos observado, pelo modelo de uma imagem-fluxo. A imagem-fluxo cumpre a fundo as potências do virtual no sentido de ser uma "imagem ao infinito", de aparentar estar sempre em vias de atualização, mas sem nunca efetuá-lo definitivamente.

\footnotetext{
${ }^{11}$ Embora mencionemos noções próximas às trabalhadas por Raymond Bellour (1997) - uma poética das passagens ou um regime de um entre-imagens, o que dá nome e organiza sua coletânea de ensaios -, pensamos que nossa abordagem acaba se afastando um pouco da deste autor. Bellour trabalha com esses termos, principalmente nas intersecções do cinema/ vídeo com a fotografia/ fotograma. A questão para ele é explorar as potências liberadas por essa imagem única ou imóvel. De nossa parte, contudo, as passagens de imagens nos concernem muito mais pelo seu fluxo vertiginoso, incessante. Ademais, a questão da desaceleração da imagem, em Naqoyqatsi, terá para nós um outro sentido, como se verá na próxima seção do texto.
} 
A imagem-fluxo é uma imagem sem fora, sem original, sem referencial. Ela não é uma imagem do real, ela cria um real. É, portanto, uma imagem efêmera, e é essa sua realidade virtual, não de ser uma imagem do efêmero, mas de ser uma imagem efêmera (BUCI-GLUCKSMANN, 2008: p. 185).

Esse novo tipo de imagem vem ainda levar às últimas conseqüências as potências mais disruptivas da imagem eletrônica, no sentido de criar uma "retórica das metamorfoses" (Cf. MACHADO, 2007), pois “(...) a imagem eletrônica é muito mais maleável, plástica, aberta à manipulação do artista (...)”, podendo-se nela “(...) intervir infinitamente, alterando suas formas, modificando seus valores cromáticos, desintegrando suas figuras. (p. 230). A imagem eletrônica pode, portanto, se voltar “(...) resolutamente na direção da distorção, da desintegração das formas, da instabilidade dos enunciados e da abstração como recurso formal” (p. 230), produzindo “(...) uma iconografia resolutamente contemporânea” (p. 231).

Após termos explorado características da imagem numérica e termos visto algumas potencialidades da imagem eletrônica, podemos perceber agora que a narrativa fílmica de Naqoyqatsi opera, em seu transcorrer, com um forte agenciamento da virtualidade inerente à imagem digital e com as potências disruptivo-dissolutivas da imagem eletrônica, criando assim, um regime predominante de uma imagem-fluxo (imagem efêmera) em constantes metamorfoses/anamorfoses, uma imagem que pode se fixar por um momento (como as constantes repetições de planos tentam o fazer), apenas para se dissolver em seguida em um novo fluxo de imagens, num movimento no qual não mais conseguimos discernir claramente que parte "pertence" a uma imagem e qual já compõe uma outra imagem a formar-se. Temos assim, a mencionada "dissolução" da noção de "plano".

As características que atribuímos a essa forma da imagem-fluxo encontram ainda numa figura/forma especial sua maior consistência. É a figura da imagem-fractal. Essa formação visual aparece no filme na forma bem conhecida das "espirais auto-semelhantes".

Nesta espiral, "cada parte da figura (...) repete a forma macroscópica predominante", de forma que "poderíamos continuar o exame [da imagem] ao infinito, 'ampliando' detalhes cada vez menores e fazendo vir à tona novas reverberações do motivo plástico principal”, até o momento em que "em algum ponto de multiplicação das formas, desabrocha um outro motivo e uma paisagem nova passa a proliferar sobre a antiga" (MACHADO, 1988: pp. 151153). Ao lidarmos com a espiral auto-semelhante, estaríamos lidando então com "um universo plástico infinito", ou ainda com "vários universos infinitos que se atravessam de forma complexa". (MACHADO, 1988: pp. 151-153). 
No filme, este imagem-fractal ${ }^{12}$ surge após uma série de passagens e transformações rápidas que se dão entre diversas imagens em movimento (dentre as quais imagens de síntese abstratas, o modelo de um tornado, ondas, e as teclas de um teclado), e a espiral é continuada por uma imagem modelada de um túnel no qual mergulhamos, com sua superfície coberta por uma sequiência de código binário interminável, que vai lentamente se transformando em textura de céu azul com nuvens brancas, até sua lenta desaparição final, em um fundo negro.
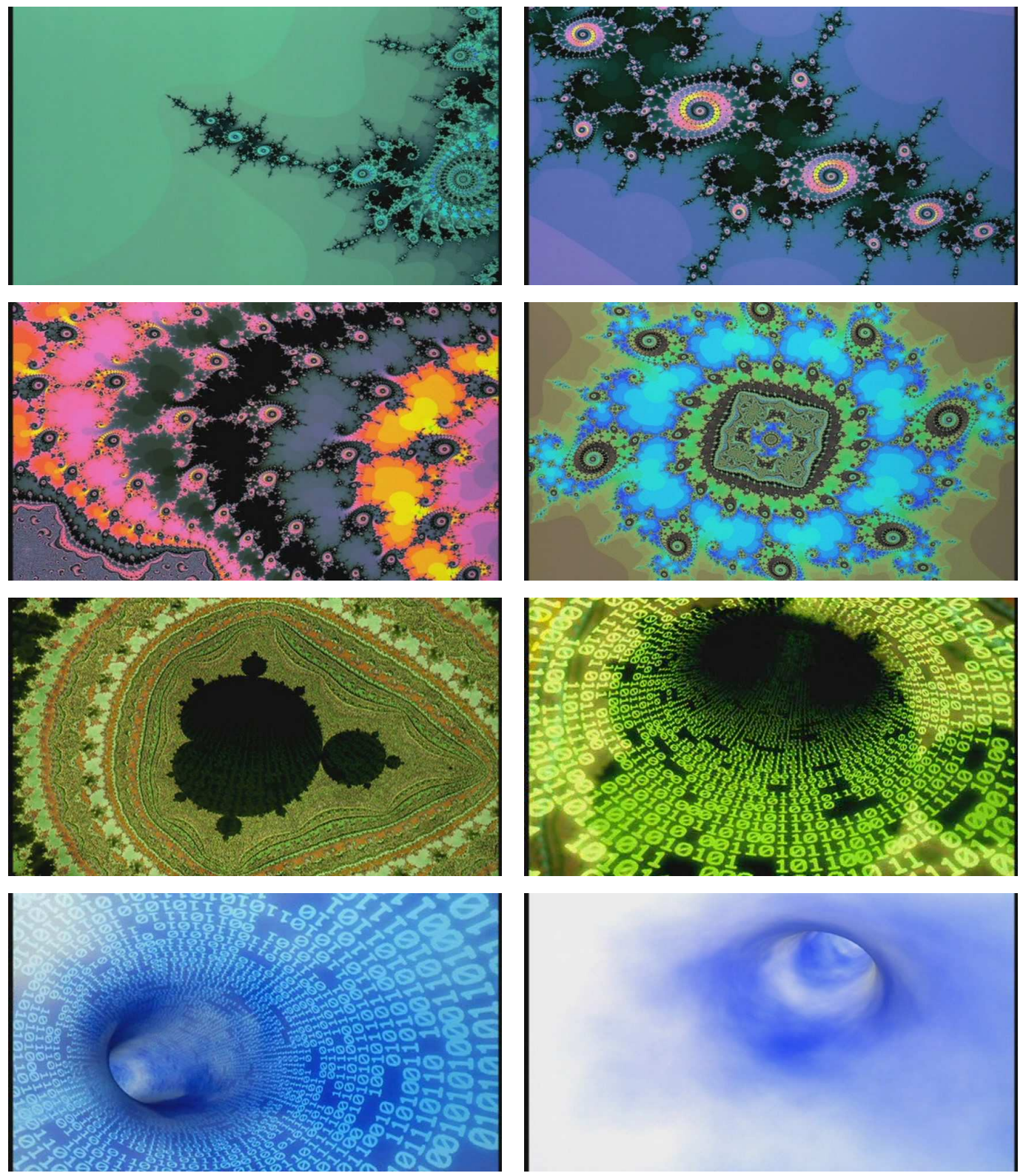

Figura 12: Imagem-fractal da espiral auto-semelhante desemboca em túnel virtual

A imagem-fractal surge não como forma fixa, mas sim em movimento. O que ocorre é que o "mergulho" que será dado no túnel binário já se inicia na própria imagem-fractal. Essa imagem-fractal como espiral em movimento sintetiza em si todo o regime que vínhamos

\footnotetext{
${ }^{12}$ A espiral aparece aproximadamente aos 16 ' de filme.
} 
trabalhando da imagem-fluxo, sendo o melhor exemplo de uma virtualidade pura, sempre num processo de atualização, mas sem nunca fazê-lo até o fim: a espiral fractal em movimento parece estar em expansão contínua, num processo infindável de "criação imagética em tempo real", uma criação que se dá através de suas estruturas ou matrizes elementares (virtuais), mas que se visualiza (atualiza) sempre de uma forma renovada. Essa imagem é um puro devir que parece nos tragar para seu centro, nos lançando para o interior da virtualidade da matriz numérica, de que o fractal advém. Daí essa imagem-fractal, no filme, ser continuada pelo túnel binário, que se atualiza com a textura de um céu sintético: um processo de incessante atualização de uma pura virtualidade.

Mas por que chamarmos a atenção aqui para as formas visuais, se já o foi feito na seção anterior? Isso porque o que exploramos agora são imagens especiais, imagensmovimento $^{13}$ especiais. São imagens-movimento às quais o movimento entra numa nova dimensão e é levado aos extremos, à aberração - e por que não, à abstração. É disso que se trata a demarcação de uma imagem-fluxo, sua manifestação privilegiada na imagem-fractal da espiral móvel e sua potência de virtualidade pura, nunca esgotada. A componente "movimento", da formulação de uma imagem-movimento, entra num novo regime. Parece agora tratar-se de dar visibilidade a movimentos, a fluxos incessantes quaisquer, muito antes de se reconhecer alguma "imagem" específica do mundo.

Retrabalhemos este panorama. Se considerarmos essa situação da multiplicação dos fluxos incessantes, da visibilidade de movimentos fulgurantes que mal se esboçam e já se dissolvem, veremos que ela não está muito longe da formulação que fazem Gilles Deleuze e Félix Guattari (1997) a respeito do caos. Dizem os autores, em uma passagem tão esclarecedora quando bela:

Pedimos somente um pouco de ordem para nos proteger do caos. Nada é mais doloroso, mais angustiante do que um pensamento que escapa a si mesmo, idéias que fogem, que desaparecem apenas esboçadas, já corroídas pelo esquecimento ou precipitadas em outras, que também não dominamos. São variabilidades infinitas cuja desaparição e aparição coincidem. São velocidades infinitas, que se confundem com a imobilidade do nada incolor e silencioso que percorrem, sem natureza nem pensamento. É o instante que não sabemos se é longo demais ou curto demais para o tempo (...). (DELEUZE; GUATTARI, 1997: p. 259)

\footnotetext{
${ }^{13}$ Gilles Deleuze (1985) cria o conceito de imagem-movimento ao apresentar uma classificação de diferentes tipos de signos formados com a imagem cinematográfica, que não está "em movimento", mas que contém em si mesma um automovimento: "nem sequer há uma 'relação' entre a imagem e o movimento, o cinema cria o automovimento da imagem” (1992: p. 84). Tomemos esquematicamente as imagens-movimento como "cortes móveis da duração, imagens-mudança, imagens-relação, imagens-volume" (1985: p. 21).
} 
Ora, parece que o percurso que vínhamos tateando desde o levantamento das múltiplas camadas dessa arqueologia visual, sobrevoando as potencialidades de uma dimensão de virtualidade e nos lançando num movimento de fluxo dissolutivo incessante, parece que todo esse horizonte compõe uma espécie de plano caótico, se nos apoiarmos na formulação que fazem dele Deleuze e Guattari: um plano de "velocidades infinitas", ou de "variabilidades infinitas cuja desaparição e aparição coincidem”. Parece que a multiplicação dos elementos visuais, as metamorfoses e anamorfoses constantes, e os fluxos visuais múltiplos, seguem todos, em Naqoyqatsi, no sentido de alçar a imagem-movimento, a imagem-fluxo, às velocidades mais estonteantes, tentando criar "variabilidades infinitas".

Para o espectador que assistira anteriormente aos outros filmes da trilogia Qatsi, não é muito estranho ou distante esse regime imagético-narrativo que dá uma potente dimensão aos movimentos, aos fluxos. O primeiro filme da trilogia, Koyaanisqatsi (1983), já possuía uma situação fílmica de criação de uma "experiência da aceleração" (Koyaanisqatsi = vida fora de equilíbrio).
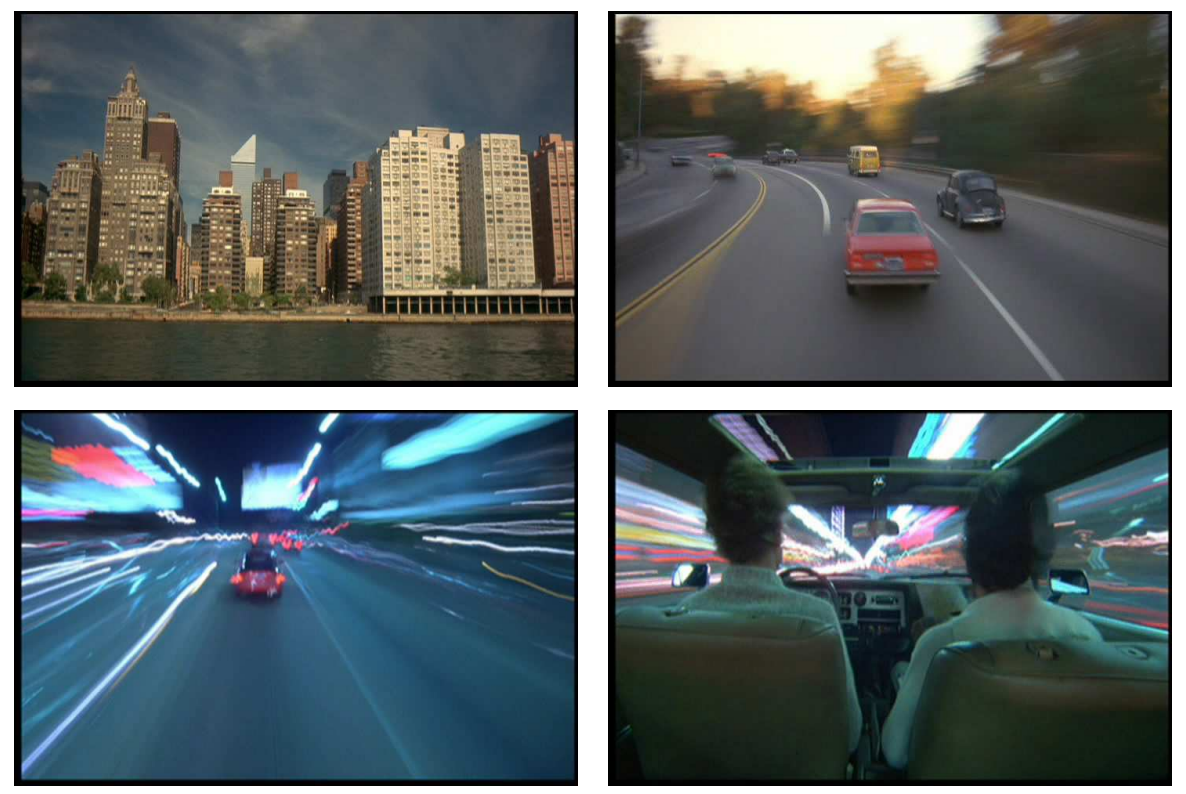

Figura 13: Aceleração em Koyaanisqatsi

Essa situação era o próprio motor propulsor da narrativa fílmica: uma narrativa que opera inicialmente por enquadramentos fixos que registram os (objetos) móveis - as tomadas estáticas das paisagens e da cidade; passa pela consecutiva absorção, pela câmera, dos movimentos - câmera móvel, conduzida por um operador ou acoplada a veículos; até obter um movimento levado ao paroxismo, onde não mais podemos reconhecer as imagens: profusão de estímulos luminosos - no caso em que a câmera acoplada ao veículo registra imagens aceleradas, obtendo imagens quase abstratas (Cf. BONOTTO, 2009: p. 41). 
De modo que podemos afirmar que o germe caóide era já um impulso presente em Koyaanisqatsi: no primeiro filme da trilogia já havia uma aceleração vertiginosa e uma proliferação de micro-ritmos visuais, tal como ocorre agora em Naqoyqatsi, onde essas operações ganham novas dimensões.

E por esse motivo podemos falar em haverem incidências de Koyaanisqatsi em Naqoyqatsi. Elas se manifestam de duas formas principais, neste último filme. A primeira delas é a proliferação de traços luminosos atravessando o espaço todo do campo visual. O exemplo mais claro disso é em um plano emblemático exatamente igual a um plano de Koyaanisqatsi: uma tomada fixa noturna captada de forma acelerada, onde vemos os traços vermelhos das luzes das fileiras intermináveis de carros que passam, sempre pela mesma trilha do veículo anterior ${ }^{14}$. Além desse exemplo, existem os casos dos planos de proliferações luminosas de outras cores, como os planos de chuva de estrelas/meteoros, ou ainda os planos realizados com câmera acoplada em veículos acelerados.
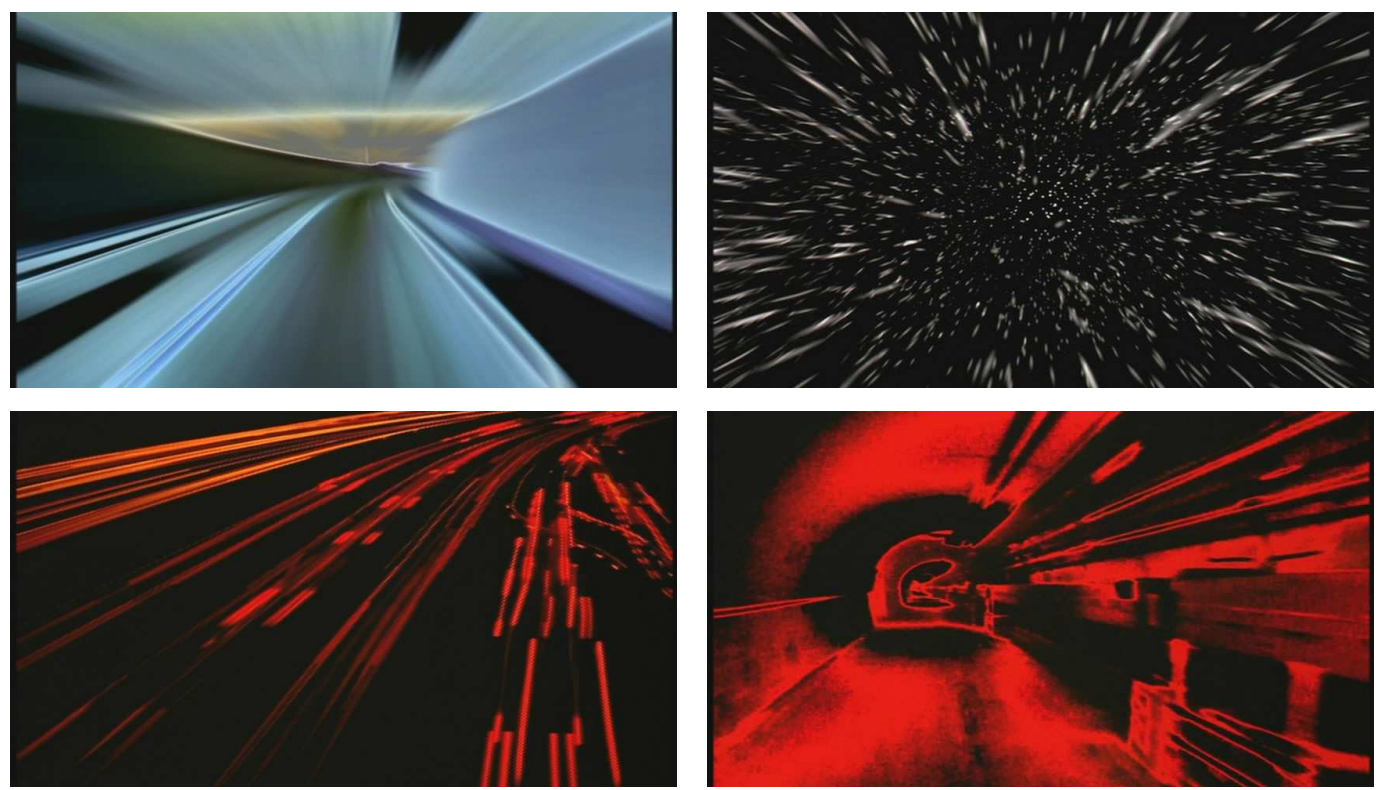

Figura 14: Incidências de Koyaanisqatsi em Naqoyqatsi

A segunda forma de manifestação da incidência de Koyaanisqatsi em Naqoyqatsi é através da componente sonora. Em diversas passagens do filme, surgem momentaneamente incorporados ao tecido musical já estabilizado, frases melódicas curtas, de padrões de notas em repetições, executadas por um teclado eletrônico. Esse padrão musical com sonoridade de teclado eletrônico é o elemento de criação principal das linhas musicais de Koyaanisqatsi, tornando-se seu signo sonoro característico. Quando essas curtas frases musicais eletrônicas irrompem então em Naqoyqatsi, há um resíduo de operação e talvez um estranhamento, já que

\footnotetext{
${ }^{14}$ Aproximadamente aos 58' de filme.
} 
o tecido musical de Naqoyqatsi é constituído quase exclusivamente por instrumentos da família das cordas, metais e percussão orquestrais, criando uma ambiência sonora "clássica". A evocação de Koyaanisqatsi, com isso, é imediata.

As duas formas de incidência podem irromper autonomamente, como o fazem na maior parte das vezes, como podem também irromper simultaneamente, como o fazem no plano citado dos traços luminosos vermelhos dos carros. Nessa situação, a energia do resíduo deixado por essa operação de incidência dupla é grande, de modo que contamina até o próximo plano, onde uma câmera acoplada a um veículo percorre um imenso túnel: esse plano do túnel acaba totalmente colorizado de vermelho.

Notada essa continuidade, em Naqoyqatsi, de movimentos e processos iniciados em Koyaanisqatsi, devemos, contudo, apontar um diferencial entre os dois. É que em Koyaanisqatsi há um impulso integral do movimento no sentido de sua aceleração, que parece ser um fim buscado durante toda a narrativa. Já em Naqoyqatsi, não parece haver essa continuidade progressiva de aceleração integrando a narrativa. Os impulsos parecem ser mais fragmentários, mais dispersos. O que ocorre é que aqui há ainda uma outra força em jogo, que cria movimentos em sentido contrário, se assim o podemos dizer, e que torna o regime imagético-narrativo mais caótico, por assim dizer. Para compreender melhor esse jogo de forças, devemos passar à próxima seção.

\section{Desaceleração/controle}

Se quisermos desenvolver e levar adiante esta nova dimensão que nos propomos aqui a explorar, devemos começar a fazê-lo primeiro através da observação de dois tipos de planos. (Diferente do que se passou na seção precedente, essas imagens que exploraremos agora mantêm suas qualidades de planos, e mais, de tomadas).

O primeiro tipo desses planos seria aquele que chamaremos de "teste", em referência ao test drive. $\mathrm{O}$ procedimento de test drive é comumente utilizado na indústria e comércio automotivos e se refere à condução de um veículo para avaliar seu estado de funcionamento geral, desempenho e operacionalidade. Em um sentido mais amplo, o test drive pode ser utilizado em relação à análise ou teste de qualquer produto ou coisa. Os planos de teste aparecem no filme, sobretudo em duas formas principais: teste de colisão ${ }^{15}$ e teste bélico ${ }^{16}$.

\footnotetext{
${ }^{15}$ Aparecem aproximadamente aos 60' de filme.

${ }^{16}$ Aparecem aproximadamente aos $67^{\prime} 40$ '” de filme.
} 
A primeira forma apresenta planos de testes de colisão automotiva, com a câmera, registrando imagens desaceleradas, posicionada muito próxima dos bonecos que "manobram" o veículo, através do que podemos ver que a força do impacto estilhaça a janela frontal e projeta fortemente esses corpos inertes para fora dos assentos, quase não podendo ser segurados pelos cintos de segurança. Segue-se ainda um teste com bonecos no interior de um avião, como que controlando o comportamento desses corpos que se debatem, também em câmera lenta, em relação às forças da gravidade.
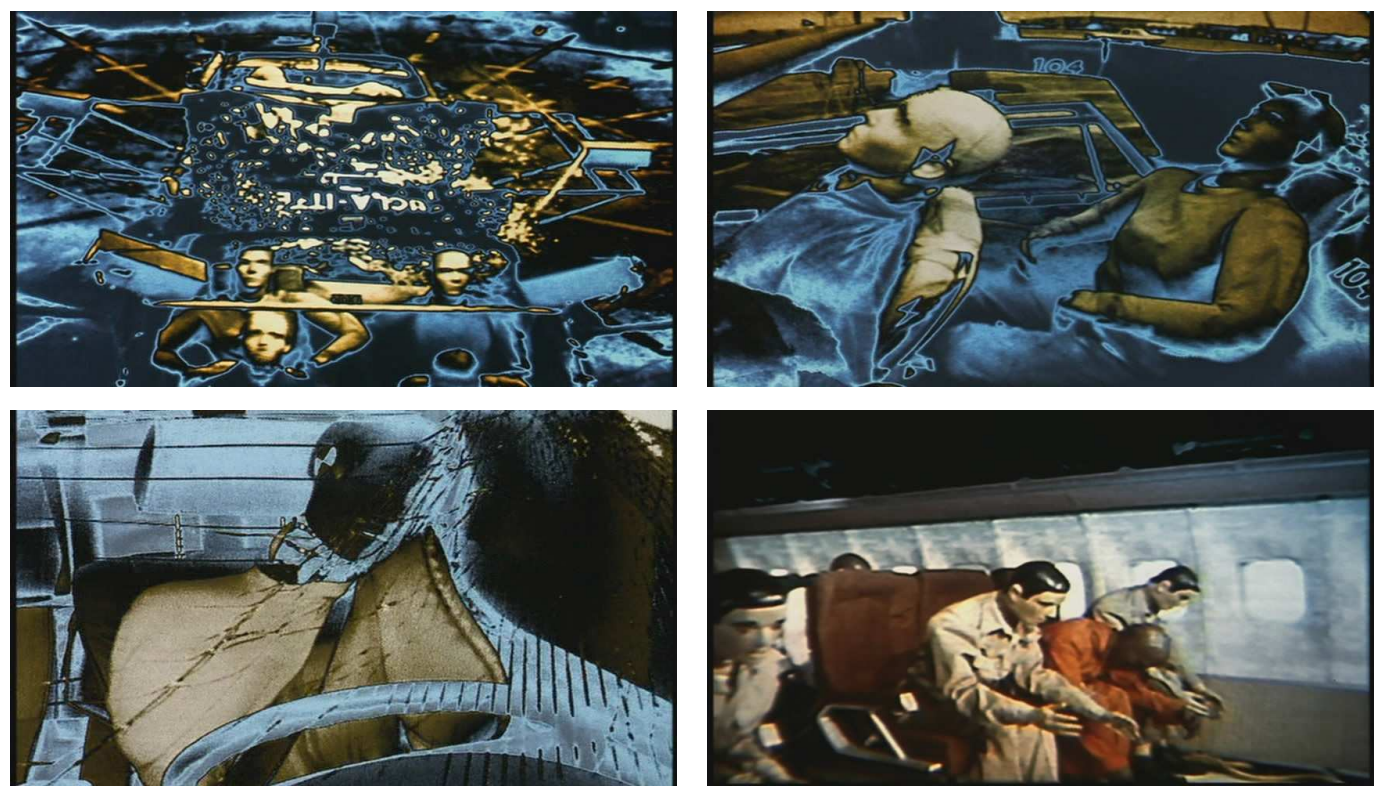

Figura 15: Testes de colisão

A segunda forma, o teste bélico, aparece um pouco à frente, através das inúmeras tomadas onde o poderio bélico está em ação: os napalms lançados que carbonizam grandes áreas com árvores, as bombas lançadas explodindo veículos ou grandes estruturas, os disparos de diversas armas, ou ainda os lançamentos de mísseis e foguetes por aviões e silos militares. Todas essas tomadas, dos dois tipos de testes, nos apresentam imagens desaceleradas.
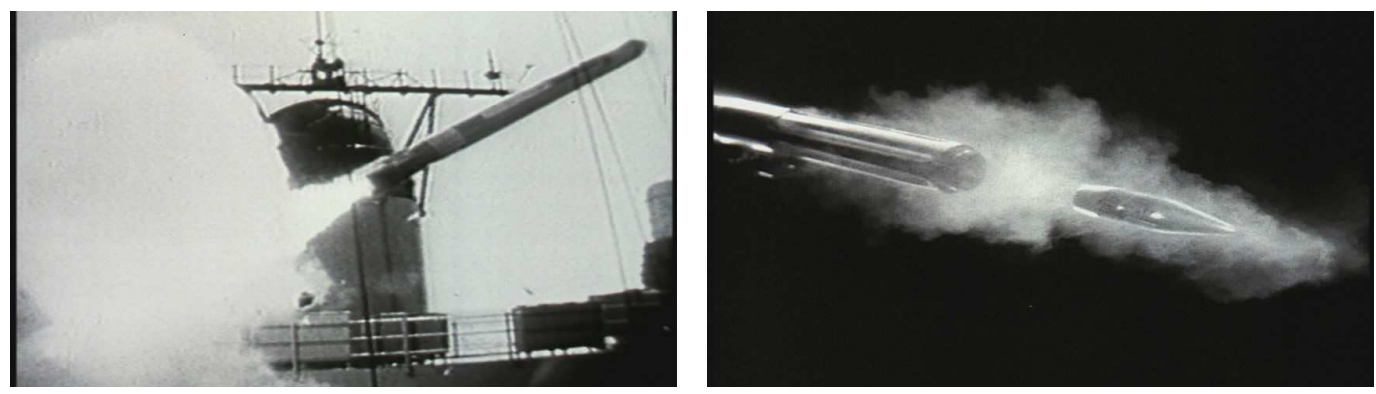

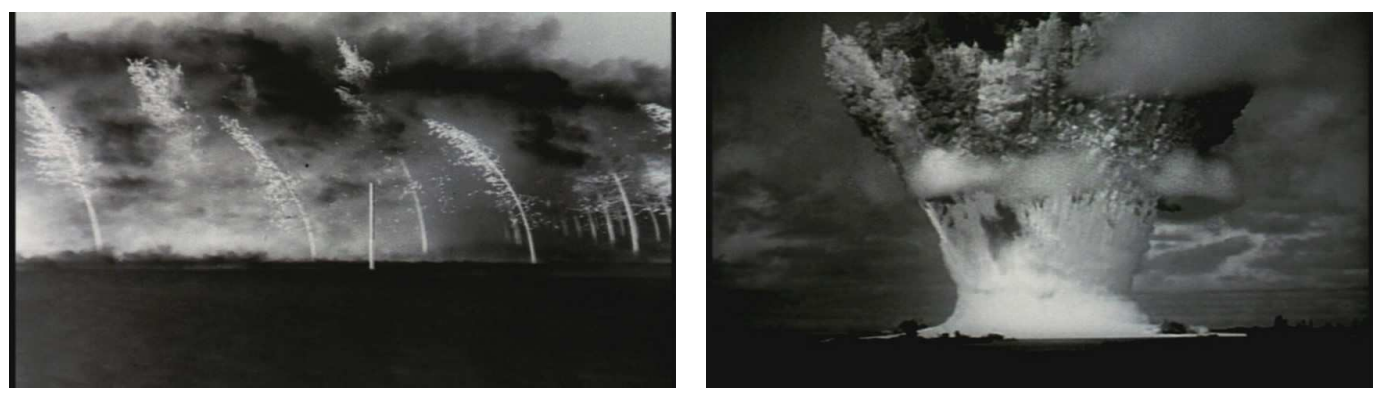

Figura 16: Testes bélicos

Passemos ao segundo tipo de plano que nos será útil em nossa análise: os planos de estudos de movimento (motion studies). Esses planos aparecem inicialmente com o do homem correndo nu, sobre um fundo preto, imagem que vemos ser montada num painel combinado com outras ações ${ }^{17}$ : homens martelando, lutando, arremessando, saltando, caminhando. Há também manifestações mais a frente destes estudos de movimento, com o plano do búfalo galopando ${ }^{18}$ e do zoótropo ${ }^{19}$. As imagens originais das quais esses planos derivam, antes cortes imóveis de ações num espaço, foram re-colocadas em movimento pela narrativa fílmica.
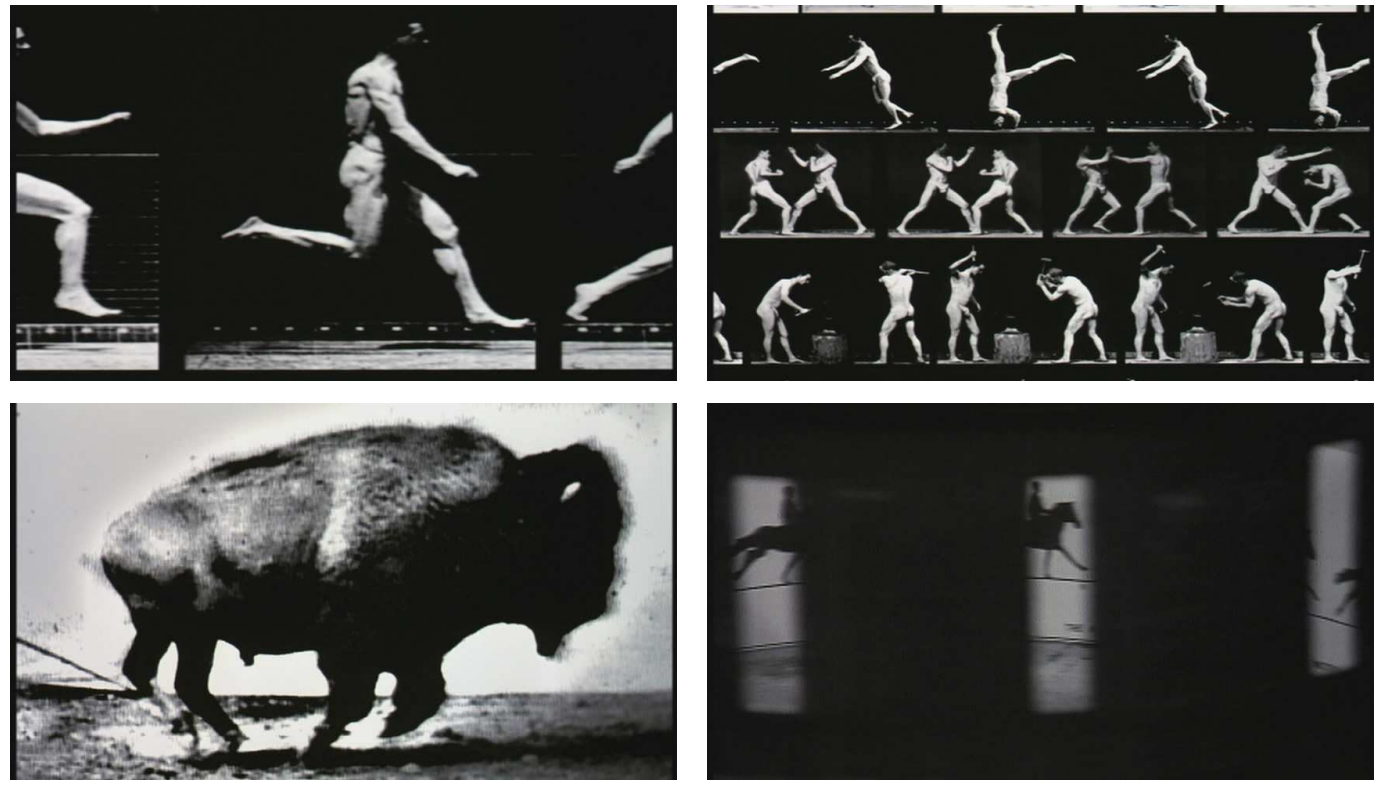

Figura 17: Estudos de movimento: figura humana, búfalo galopando e zoótropo

Os planos dos homens realizando algumas ações e o do búfalo são sequiências fotográficas realizadas por Eadweard Muybridge, em suas séries dos Motion Studies (Cf. MUYBRIDGE, 1907; 1985). Muybridge é reconhecido na história do cinema pela sua

\footnotetext{
17 Aparece aproximadamente aos 22'45'. As séries fotográficas combinadas aqui são algumas dentre as ações figuradas no trabalho The human figure in motion de Eadweard Muybridge (1907).

18 Essa imagem aparece aproximadamente aos 59'15', de filme, e provém de Buffalo Galloping, placa fotográfica $\mathrm{n}^{\circ} 31$ no trabalho Horses and other animals in motion de Muybridge (1985).

${ }^{19}$ Zoetrope, um dos "brinquedos óticos" precursores do projetor cinematográfico. Surge na narrativa logo depois do búfalo galopando.
} 
descoberta de que "o movimento pode ser analisado fotograficamente em suas partes componentes", e pela invenção de um dispositivo ótico (Zoopraxiscope), num estágio intermediário entre o uso de animações desenhadas e de imagens fotográficas, capaz de colocar em movimento sequiências visuais isoladas, criando a ilusão de restituir o movimento original (Cf. MACDONALD, 1993: p. 9) - um precursor do cinematógrafo.

O que permeava essas diversas experiências de decomposição fotográfica do movimento era um interesse ou curiosidade científicos, no sentido de se realizar um inventário analítico dos estados instantâneos consecutivos dos corpos em movimento. A questão da análise era, portanto, central, ainda que seu interesse pudesse vir da parte de artistas, fotógrafos, animadores, zoologistas ou qualquer outro interessado no assunto conforme fora indicado pela "prescrição de leitura" que consta no início do trabalho de Muybridge (Cf. 1985).

Peguemos agora esse interesse analítico dos planos de estudos de movimento (exemplos dos homens agindo, búfalo galopando e o zoótropo) e o relacionemos com o tipo de plano anteriormente evidenciado, o dos testes de colisão e bélicos. Vemos, com isso, um interesse analítico comum que estaria por trás de ambos - a observação minuciosa da ação ou interação entre corpos se desenvolvendo no tempo. Esta observação é facilitada por: a) de um lado pela decomposição em cortes instantâneos razoavelmente espaçados, dos diferentes estágios de um movimento (estudos de movimento); b) de outro, pelo registro de um "corte móvel sobre o tempo" ${ }^{20}$, um tempo que é ainda distendido pelo uso da câmera lenta (testes de colisão e bélico). Pelas duas vias, (essencialmente opostas,) o que parece ocorrer é procederse em direção a uma "imobilização do movimento". Imobilização realizada para uma otimização de análise das condições dos corpos em cada momento de sua ação/interação no tempo.

Tomando-o como impulso subterrâneo dessas duas matrizes imagéticas (planos de testes e estudos de movimento), podemos agora expandir este impulso analítico para muitas outras imagens do filme, em especial para as tomadas que apresentam atletas em treinamento (corredores, ginastas alongando, saltadores, lutadores, esgrimistas, esquiador, nadador, patinador, arremessador, boxeadores, etc.) ou para os planos publicitários que apresentam carros e outros produtos. Os planos dos atletas treinando situam-se, inclusive, próximos do

\footnotetext{
${ }^{20}$ Gilles Deleuze propõe as duas formulações: "corte imóvel do espaço" e "corte móvel sobre o tempo", que abarcariam, respectivamente, o domínio da imagem pura, estática, ou o domínio de uma imagem-movimento, como já nos referimos em outra nota (Cf. DELEUZE, 1985: pp. 9-21). Aí estaria a distinção entre cada fotograma da película tomado em sua imobilidade, e o filme em funcionamento, que nos oferece não "o fotograma, mas uma imagem média à qual o movimento não se acrescenta, não se adiciona: ao contrário, o movimento pertence à imagem-média enquanto dado imediato" (DELEUZE, 1985: pp. 10-11).
} 
início e fim do estudo de movimento de Muybridge no mosaico de ações humanas, encadeando-se a eles em continuidade. A questão de um estudo ou monitoração constante, através da imagem, do que nela figura, impregna uma infinidade de planos. Em todos esses casos haveria o germe das análises permanentes de desempenho físico, motor, aerodinâmico, bélico, ou técnico-científico em geral. Daí a proliferação no filme, de gráficos, fórmulas, esquemas e imagens científicas.
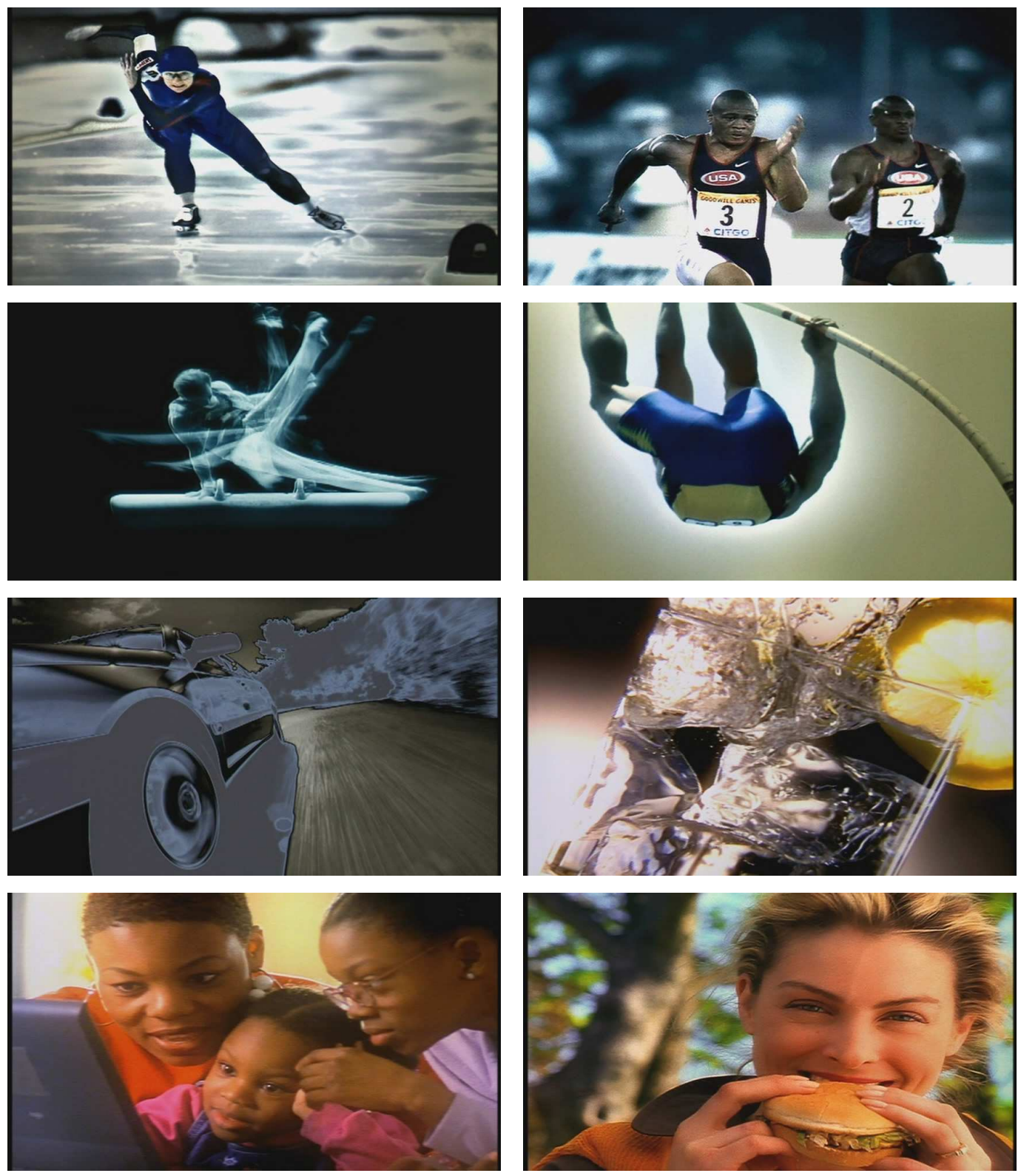

Figura 18: Análise de desempenho: atletas treinando e produtos

Mas, partindo do que acima foi exposto, poderíamos também falar em uma espécie de incidência pervertida de Powaqqatsi (1988), o segundo filme da trilogia, em Naqoyqatsi. "Pervertida" pois, em Powaqqatsi, a desaceleração da imagem era predominante, mas lá, essa temporalidade lenta estaria ligada a um princípio ritualístico, fabulativo, de celebração das atividades, formas e movimentos humanos representados. No mosaico visual cultural que 
Powaqqatsi apresentava em toda a sua primeira parte, havia um movimento geral de celebração de cada fragmento, de sua integração entre os outros adjacentes (pensemos nos raccords visuais entre planos com movimentos ou gestos parecidos, como nos rituais ou trabalhos manuais) e integração também com o meio (relembremos as diversas tomadas aéreas exibindo casas "soltas" nas montanhas, ou pequenos povoados "inseridos" em região rural muito extensa).
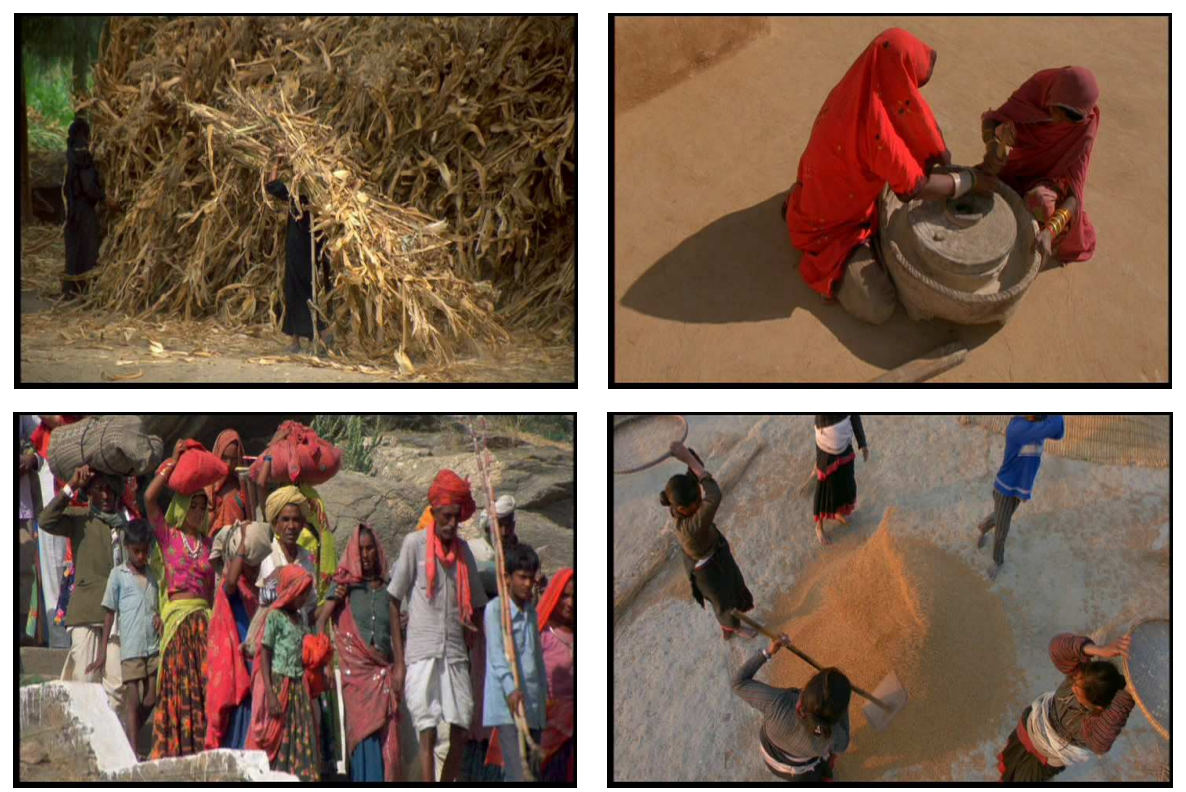

Figura 19: Rituais e trabalhos manuais em Powaqqatsi

Já em Naqoyqatsi, entretanto, esse procedimento de desaceleração que anteriormente realizava a celebração, salta desse universo orgânico, do vivo, do heterogêneo, e vem agora para uma dimensão mais técnica, distanciada, processada, padronizada. Para compreender melhor essa transformação, devemos recordar algumas características das imagens técnicas, imagens que, já o advertimos, predominam em Naqoyqatsi.

As imagens técnicas teriam demonstrado sua presença no Renascimento, onde, com os estudos e dispositivos construídos na época,

a imagem se torna cada vez mais calculada, arquitetada, conceitualizada, construtiva, encarnando a própria utopia de um total controle do visível. A partir do Renascimento, a paisagem visualizada no quadro advém cada vez mais sóbria, encorpada, matematicamente controlada, regida por conceitos de simetria e de funcionalidade. Em todos os sentidos, trata-se de um efeito de conhecimento, primado do intelecto sobre a mão ou, mais precisamente, um empenho na direção de uma imagem cientificamente verossímil, a própria essência do que agora estamos chamando de imagem técnica. (pp. 224-225) 
Esse pano de fundo secular nos relembra que "a fotografia é filha legítima da iconografia renascentista" (p. 227), não apenas por sua produção se dar através do mecanismo de base da câmera obscura (grande mecanismo criador de imagens técnicas), mas por que "a sua principal função (...) será dar continuidade ao modelo de imagem construído no Renascimento, modelo marcado pela objetividade, pela reprodução mimética do visível e pelo conceito de espaço coerente e sistemático" (MACHADO, 2007: p. 227).

Quando passamos então da imagem fotográfica para a imagem digital,

num certo sentido, trata-se de um retorno aos cânones renascentistas de coerência e objetividade. Mais que um retorno, a imagem digital aparece como uma verdadeira hipertrofia dos postulados estéticos do século $\mathrm{XV}$, na medida em que ela realiza hoje o sonho renascentista de uma imaginação puramente conceitual, em que a imagem seria encarada e praticada como uma instância de materialização do conceito. (pp. 231-232)

Nesta rápida linha que traçamos de um desejo latente de automação ou controle cada vez maiores dos processos de mediação técnica na produção da imagem, o que a imagem numérica - este tipo especial de imagem técnica - nos oferece é enfim realizar essa "utopia de um total domínio do visível, de um controle absoluto do processo gerador da imagem, até mesmo nos seus detalhes mais microscópicos" (MACHADO, 2007: p. 233).

Lembremos que, ao estudarmos as características da imagem numérica, havíamos compreendido que em verdade não há imagem na memória da máquina, mas sim objetos virtuais construídos, objetos que podem sofrer "qualquer sorte de manipulações, através da pura e simples alteração de seus valores numéricos" (MACHADO, 1996: p. 60).

Podemos agora retornar agora ao ponto no qual nos encontrávamos, a respeito das incidências de Powaqqatsi em Naqoyqatsi.

Compreendendo a dimensão de "controle do visível" que a imagem numérica possuiu, podemos então relacioná-la à questão que explorávamos, dos estudos de movimento e testes de desempenho. Há um movimento que liga todas essas imagens estudadas por nós e que se alastra por todas as restantes, que tem na análise e no teste dos movimentos, ações, produtos e forças, apenas um meio para se exercer um controle. Isso está intimamente ligado ao aspecto "técnico" ou "científico" que atravessa muitas das imagens do filme - já notamos a proliferação dos gráficos, fórmulas, esquemas, etc.

Mas devemos ir um pouco mais a fundo em nossas escavações nessa arqueologia visual, pois este pretenso domínio de um cientificismo analítico não é nem um pouco "neutro" ou "objetivo". O impulso de controle se exerce de forma mais estarrecedora. Não é apenas um 
controle do visível, das possibilidades de interação ou simulação do visível. É o controle da própria vida que se faz representar no filme. Todas as tomadas dos atletas treinando ganham uma nova dimensão agora: correr, saltar, mergulhar, arremessar, são todas modalidades olímpicas. Podemos agora enunciar um espectro que assombrava um plano em preto e branco dentre os planos de saltadores ornamentais ${ }^{21}$.
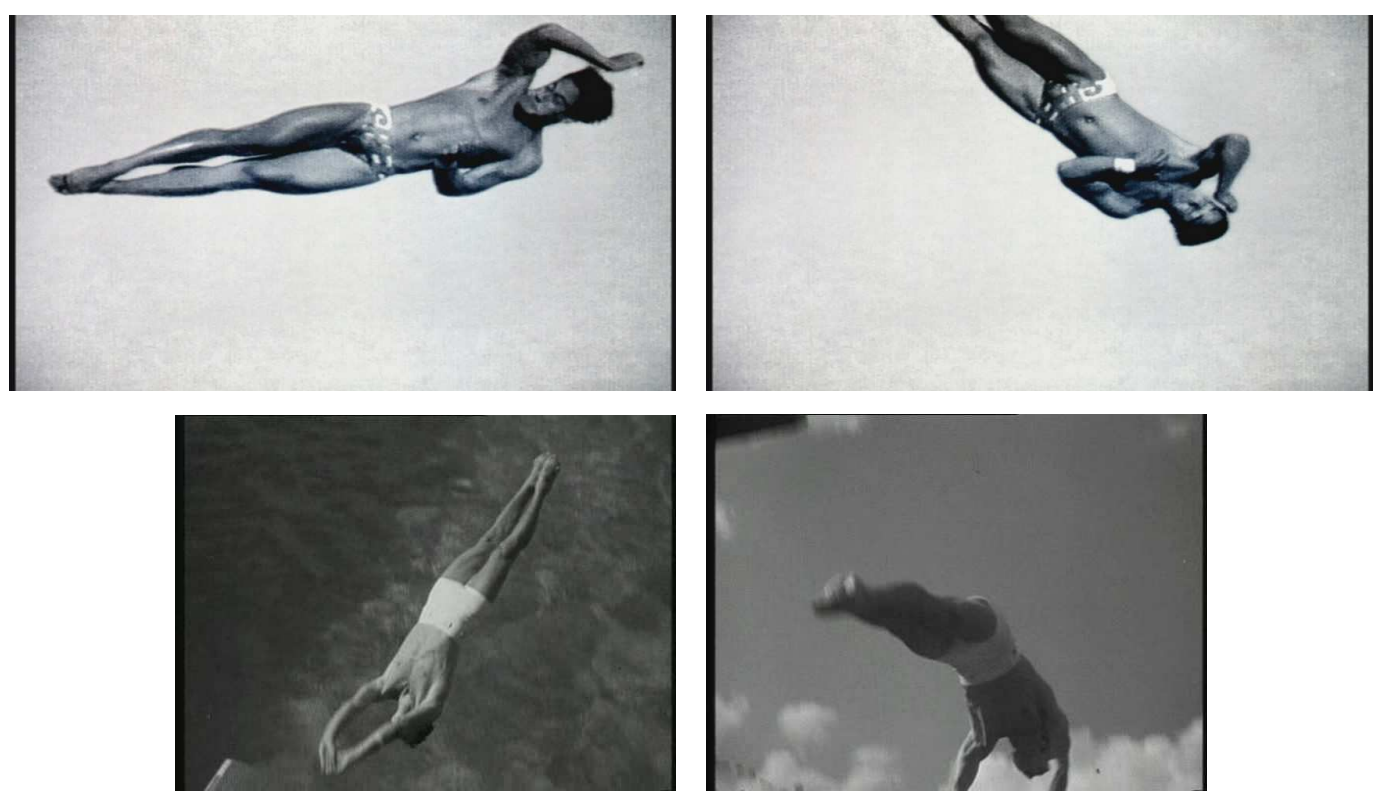

Figura 20: Salto ornamental em Naqoyqatsi (duas primeiras) e Olympia (duas últimas)

Ocorre que este é um plano idêntico às séries dos saltadores ornamentais que figuram em Olympia (1938) ${ }^{22}$ de Leni Riefenstahl, e conhecida é a adequação e contribuição da prática dessa cineasta com o projeto nazista de uma "engenheirização bio-estética". Riefenstahl faz uso intenso em Olympia, da técnica de captação desacelerada das imagens dos atletas. Mas então a desaceleração da ação não realiza uma celebração da mesma forma que ocorre em Powaqqatsi. A desaceleração em Olympia, caso contemple alguma coisa, seria antes um ideal clássico das formas, proporções e simetrias dos corpos, que Riefenstahl se esforça por extrair visualmente dos atletas filmados ${ }^{23}$. A desaceleração das imagens dos atletas em exercício em Olympia vem realizar uma "análise" das performances físicas, no sentido de se almejar sempre uma superação da condição humana rumo a uma "bio-máquina" sempre aperfeiçoada.

\footnotetext{
${ }^{21}$ Surgidos, em Naqoyqatsi, aproximadamente aos 25'15',

${ }^{22}$ Série que se inicia na parte 2 deste filme alemão, aproximadamente aos 81 '.

${ }^{23}$ Quanto a isso, muito emblemática é a transição entre dois planos da abertura da primeira parte de Olympia, onde através da montagem (crossfade) se funde a carne em pedra, numa tentativa de reviver a estatuária clássica de uma antiguidade em ruínas - o Discóbolo de Míron - num corpo bem torneado de um atleta contemporâneo que manifestaria um ideal de corpo apreciado pelo "pensamento estético" nazista. Esse "pensamento estético" nazista é bem analisado em Arquitetura da Destruição (Peter Cohen, 1989).
} 
Temos então enunciado o espectro que vem assombrar todas as tomadas de atletas em movimento em Naqoyqatsi: é esse espectro do impulso de controle, que teria um dia aparecido em imagens muito semelhantes, em Olympia $^{24}$.

Esse fantasma do controle ainda tomará outras formas em Naqoyqatsi, através de procedimentos de multiplicação que se bifurcarão na clonagem (como no plano duplo sobreimpresso da ovelha, ou dos incontáveis microorganismos em um recipiente, ou ainda do movimento de zoom out que revela uma superfície branca coberta por bebês recém-nascidos), e na padronização (como nos diversos exemplos de exércitos marchando e grupos como os de ciclistas e corredores, que realizam sistematicamente os mesmos movimentos), mas essencialmente o que há aqui é um impulso que procura controlar tanto a imagem, em todas as suas formas, quanto a vida, em suas variadas formas.

Por fim, esse movimento de desaceleração para máximo controle, ao chocar-se com o movimento contrário, que é um movimento de aceleração e fluxo incessantes, caotizantes; o choque entre ambos os movimentos cria esse regime imagético-narrativo formado por deslizamentos, encavalamentos, choques e conflitos contínuos, tanto de processos imagéticos, quanto de processos de vida (Naqoyqatsi = vida como guerra).

E foi somente através da efetuação dessa arqueologia visual (cujas camadas ainda poderiam ser exploradas de outras formas), que pudemos apreender a narrativa fílmica de Naqoyqatsi como criadora de um descontrole generalizado: através dos intensos choques entre um movimento acelerado, caótico, de incontáveis variações, e um movimento oposto, que visa a desaceleração como ferramenta de controle, tanto da imagem como da vida. Aceleração e/ou desaceleração são agora um pouco indecidíveis: o movimento como (des)controle.

\section{Referências bibliográficas}

AUMONT, Jacques [et al]. A estética do filme. 5a. ed. Campinas: Papirus, 2007.

BELLOUR, Raymond. Entre-imagens: Foto, cinema, vídeo. Campinas: Papirus, 1997.

BERNARDET, Jean-Claude. "A migração das imagens”. In: TEIXEIRA, Francisco Elinaldo (Org.). Documentário no Brasil: Tradição e transformação. São Paulo: Summus, 2004.

BONOTTO, André; TEIXEIRA, Francisco Elinaldo. "Biofilmografia de Godfrey Reggio". Cadernos de Pós-Graduação da Unicamp, Campinas, v. 10, n. 1, 2009.

\footnotetext{
${ }^{24}$ Seria o caso de observarmos na criação de Olympia um resíduo de operação do filme anterior de Riefenstahl, no qual mais explicitamente se vê a questão que apresentamos: O Triunfo da Vontade (Leni Riefenstahl, 1935).
} 
BONOTTO, André. Trilogia Qatsi: visões e movimentos de mundo [Dissertação de Mestrado]. Campinas: Unicamp - Instituto de Artes - Programa de Pós-Graduação em Multimeios, 2009.

. "Relação imagem-música nas narrativas da trilogia Qatsi”. Doc On-Line - Revista Digital de Cinema Documentário, v. 6, 2009.

BUCI-GLUCKSMANN, Cristine. "Le virtuel produit du réel : l'image-flux". In: DOSSE, François; FRODON, Jean-Michel (Dir.). Gilles Deleuze et les images. Paris: Cahiers du Cinéma, 2008.

DELEUZE, Gilles. A imagem-movimento. São Paulo: Brasiliense, 1985.

A imagem-tempo. São Paulo: Brasiliense, 1990.

Conversações. São Paulo: Ed. 34, 1992.

DELEUZE, Gilles; GUATTARI, Félix. O que é a filosofia?. 2a. ed. São Paulo: Ed. 34, 1997.

MACDONALD, Scott. "Godfrey Reggio". In: A critical cinema 2. Interviews with independent filmmakers. Berkeley: University of California Press, 1992.

. "Godfrey Reggio: Powaqqatsi”. In: Avant-garde film: motion studies. New

York: Cambridge University Press, 1993.

MACHADO, Arlindo. A arte do vídeo. São Paulo, Brasiliense: 1988.

. Máquina e imaginário. 2a. ed. São Paulo: Edusp, 1996.

. Pré-cinemas \& pós-cinemas. 4a. ed. Campinas: Papirus, 2007.

MUYBRIDGE, Eadweard. The human figure in motion. An electro-photographic investigation of consecutive phases of muscular actions. London: Chapman \& Hall, 1907.

Horses and other animals in motion. 45 classic photographic sequences. New York: Dover, $1985^{25}$.

TEIXEIRA, Francisco Elinaldo. "A propósito da análise de narrativas documentais". In: CATANI, Afrânio Mendes; FABRIS, Mariarosaria; GARCIA, Wilton (Orgs.). Estudos Socine de Cinema. São Paulo: Nojosa Edições, 2005.

\section{Ficha técnica}

\section{Naqoyqatsi}

Ano: 2002 / Estados Unidos / Duração: 90 min / Cor / Som Dolby SR

Direção: Godfrey Reggio / Roteiro: Godfrey Reggio

Produção: Joe Beirne, Godfrey Reggio, Lawrence Taub / Produção executiva: Steven Soderbergh / Co-produção: Mel Lawrence

Direção de fotografia: Russell Lee Fine / Fotografia adicional: Timothy Housel / Cinematografista convidado: John Bailey, A.S.C.

\footnotetext{
${ }^{25}$ Seleção de seqüências originalmente publicadas em Animal locomotion: an electro-photographic investigation of consecutive phases of animal movements, 1887.
} 
Edição e design visual: Jon Kane / Edição adicional: Bill Morrison / Efeitos visuais e reanimação de imagem: Manuel Gaulot / Animação CGI original: Manuel Gaulot, Cameron Hickey, Zachary David Medow / Direção de pesquisa de imagem: Ray Hemenez

Música: Philip Glass / Solos de cello: Yo-Yo Ma / Design sonoro: Steven Boeddeker 